\title{
A SYNOPSIS OF THE DESCRIBED NORTH AMERICAN SPECIES OF THE DIPTEROUS GENUS TIPULA L.
}

\author{
By W. G. Dietz, M. D.
}

The following synopsis is not offered to fill the proverbial long felt want, but rather that it may facilitate and lessen the labor of the student who undertakes the study of the above mentioned genus. It is based almost entirely on the original descriptions with the exception of those of Fabricius, and for these I have had to depend upon those of Wiedemann.*

Many of these fall short of completeness. Some, like those of Walker's, as was his custom elsewhere, are woefully defective. Fortunately not a few. of these have been authentically recognized and wherever such was the case and representative material was at hand, I have drawn upon this source of information. It will readily be seen that this synopsis is not merely a synoptical table in the usual sense and hence, some explanatory remarks are deemed necessary. To give more certitude to the identification of a given species, the usual differential diagnosis is followed by a short detail description. In the latter, especial stress has been laid upon the structure and formation of the hypopygium - ninth segment-and the eighth abdominal segment of the male, though in many instances no information on these points was available. All references to the apical appendages of the male hypopygium have been omitted, important and almost absolute their consideration becomes in the separation of otherwise very closely allied or similar forms, as this would have led far beyond the scope of this paper. It must be remembered that all references to the eighth and ninth-hypopygium-abdominal segments refer to the male, unless otherwise stated. $\dagger$

In the use of the synopsis, a certain margin must be allowed for the interpretation of terms used. I have, as nearly as possible made use of the identical language of the authors in their descriptions and in the translations from the Latin have kept close to the sense of the writer. What to one observer might

*Aussereuropaeische zwei fluegelige Insecten. Vol. I.

$\dagger$ The term " ninth tergite" and "ninth sternite" in the text are the equivalents of " upper and lower lamella," respectively, used by writers. 
appear as a fascia, might merely be looked upon as a spot by another and vice versa: Under the heading, "Wings Spotted," species may have been included which might with equal propriety have been placed under "wings unicolorous" and the reverse. Whenever I have been conscious of such being the case, I have endeavored to remedy the difficulty by cross-references. To those who expect this synopsis to be an easy road to the goal, disappointment will come. To determine the relative position of a given form and then by close study of the original description and whenever possible, of the type, the student should be enabled with certain limitations, to determine whether a given form is described or not. To the critic this paper will furnish a rich field, more so perhaps, than the time and labor bestowed upon it should warrant.

Following the synopsis, I have added a list with habitat and bibliography of these species not contained in Prof. Aldrich's catalogue.

1. Wings normal in size in both sexes .............................

Wings reduced in size, or vestigial, at least in the female . . . . . . . . . 165

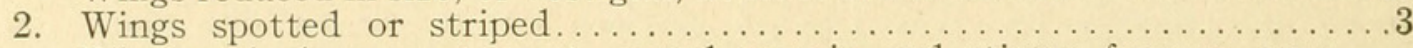

Wings unicolorous; at most, costal margin and stigma fuscous, or a white, hyaline spot before the stigma, more rarely another behind it; veins may be margined with fuscous . . . . . . . . . . . . . . . . . $87^{*}$

3. Wings spotted, marbled or clouded......................... 4

Not as above, but the costal margin, fifth longitudinal vein and posterior cross-vein more or less broadly margined with fuscous, apex of wing frequently infuscate; generally a pale hyaline vitta in the second basal cell ............................................. 79

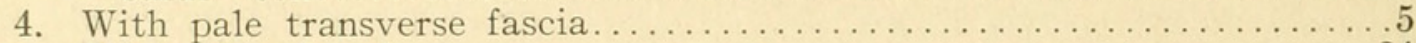

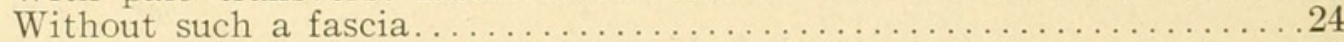

5. Wings conspicuously variegated with dark fuscous . . . . . . . . . . . . . 6

Wings not, or inconspicuously variegated with fuscous ............ 15

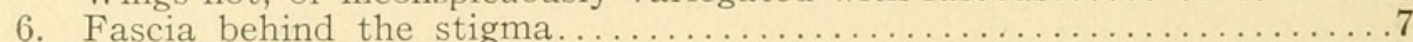

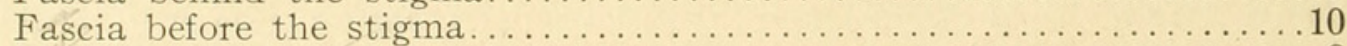

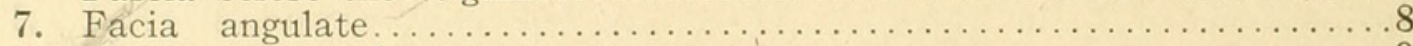

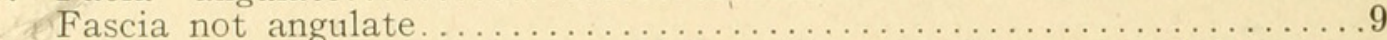

8. Joints of flagellum bicolorous. Yellow, thoracic vittæ gray; abdomen with dorsal stripe, ninth tergite narrowly emarginate in the middle; with two, rather sharp teeth from the middle of the posterior margin, lateral angles produced; ninth sternite very deeply and broadly divided; pleural plates distinct. Length $12-13 \mathrm{~mm}$. Eight sternite

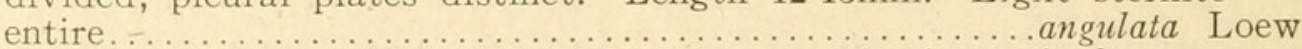

Joints of flagellum unicolorous. Mcsonotum with about six fuscous, somewhat irregular lines, the middle pair more widely separated anteriorly; abdomen trivittate; eight sternite entire; hypopygium medium-sized, ninth tergite with rather broad V-shaped emargination, its margin with several teeth; ninth sternite with $V$-shaped emargination; pleural plates distinct. Length $14-23 \mathrm{~mm}$....trivittata Say

*There may be an indistinct fuscous spot over the origin of the praefurca. The whitish spot before the stigma is called ante-stigmal spot, in the text. 
9. Fascia does not extend beyond the fourth posterior cell; joints of flagellum bicolorous. Brown; three mesonotal stripes, margined with darker brown; abdomen trivittate; posterior margin of ninth tergite with two triangular projections, between which is a deep, narrow U-shaped incision; ninth sternite with deep V-shaped incision; pleural suture distinct. Length $14-19 \mathrm{~mm}$...........................

Fascia reaches the posterior wing margin; joints of flagellum fuscous. Brown; antennæ long; mesonotal vittæ very broad; abdomen trivittate posterior margin of segments yellowish; hypopygium small, ninth tergite with a small, ninth sternite with deep and rather broad inci-

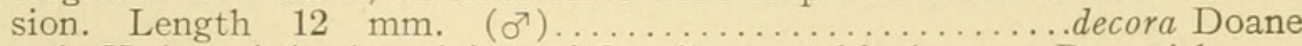

10. Fascia V-shaped, broken; joints of flagellum not bicolorous. Brownishyellow, mesonotal vittæ broad. Abdomen spotted, trivittate; ninth tergite tumid, posterior margin with broad crescent-shaped incision, in the middle of which is a small semi-circular incision; posterior margin of ninth sternite bearing a pair of leaf like appendages. Length

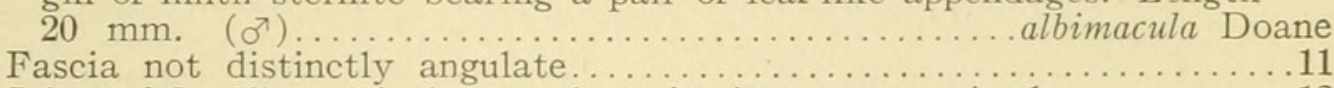

11. Joints of flagellum unicolorous; thoracic vittæ not margined............12

Joints of flagellum bicolorous; thoracic vittæ margined; posterior cells 1-3 infuscate. Dark-yellowish; mesonotal vittæ broad; abdomen conspicuously trivittate. Length $14 \mathrm{~mm}$. (o )........ fuliginosa Say

12. Posterior cells 1-3 more or less white. Gray; mesonotal vittæ broad; abdomen with three stripes; ninth tergite with median impression and slight incision; posterior margin of ninth sternite with a broad, blunt triangular process; pleural suture present. Length $17 \mathrm{~mm}$.

vittatapennis Doane albovittata Doane sgn.

Posterior cells 1-3 not white albovillata D.............13

13. Posterior margin of abdominal segments not paler. Brown; metanotum with three gray lines, margined with fuscous. Abdomen with dorsal stripe; ninth tergite with deep, broad V-shaped incision; ninth sternite with deep, very narrow incision. No pleural suture. Length 11

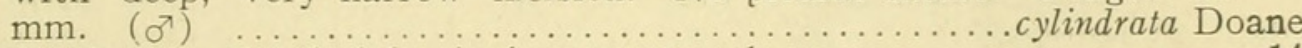

Posterior margin of abdominal segments paler

14. A white spot in middle of first basal cell. Yellowish; mesonotum with four brown stripes. Abdomen trivittate; eight sternite produced and narrowed behind, with shallow, rounded incision; hypopygium large, ninth tergite with a slight depression and two very small points; ninth sternite with shallow, rounded incision containing a pair of processes; nearly all the veins bordered with whitish. Length $17 \mathrm{~mm}$.. spectabilis Doane

First basal cell without a white spot. Brown; mesonotum gray with five brown stripes; abdomen trivittate; ninth tergite with deep median furrow, posterior margin with small $\mathrm{V}$-shaped incision; ninth sternite with broad deep incision containing two tumid processes. Length

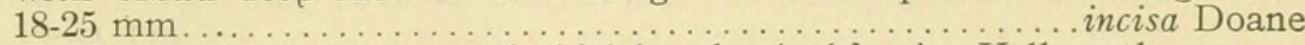

15. Apex of wings blackish; a broad whitish, subapical fascia. Yellow, thorax trivittate; abdomen with dorsal line and indistinct lateral lines.

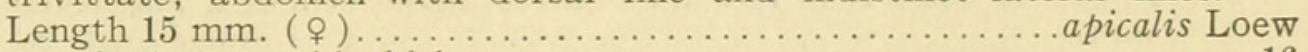

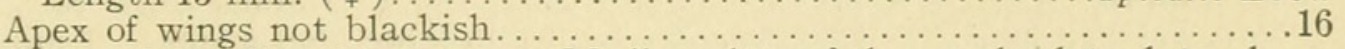

16. Joints of flagellum bicolorous. Median vitta of thorax obsolete, lateral vittæ very distinct, fuscous; abdomen pale, last two segments and posterior margin of the remaining ones, dark fuscous; hypopgyium large, ninth tergite prolonged posteriorly into a median, laterally compressed, bladelike process; ninth sternite with broad V-shaped incision, prolonged anteriorly into a narrow slit, from the base of which project two long setæ. Length $9-12 \mathrm{~mm}$........... fasciata Loew

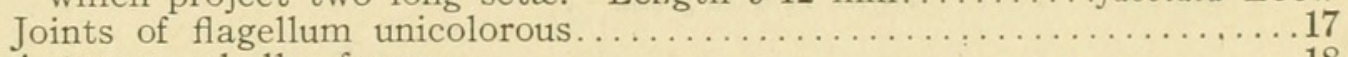

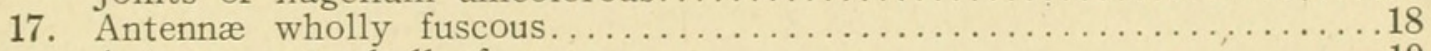

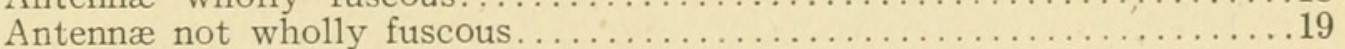


18. Origin of praefurca fuscous; mesonotum with six brown stripes, median pair broad, conspicuous. Brown; lateral and posterior margin of abdominal segments paler; eight sternite with median, short, two lobed appendage; hypopygium small, elongate, ninth tergite with deep $\mathrm{V}$-shaped incision; ninth sternite narrowly divided in almost its entire length. Length $11 \mathrm{~mm}$. $\left(\sigma^{7}\right) \ldots \ldots \ldots \ldots \ldots \ldots \ldots \ldots \ldots \ldots \ldots$ tristis Doane

Origin of praefurca not fuscous; mesonotum with three dark stripes, each of which is divided by a light brown line. Brown; lateral margin of abdominal segments broadly, posterior narrowly paler; ninth tergite with deep, narrow V-shaped incision; no pleural suture. Length

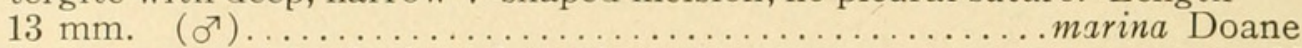

19. A fuscaus spot at beginning of praefurca ........................... 20

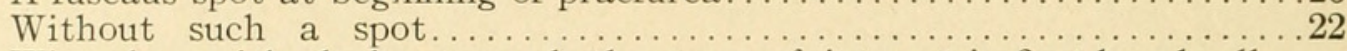

20. Wings brownish, darker towards the apex, a faint spot in first basal cell, a whitish spot in posterior margin of axillary cell. Yellow; mesonotum with four stripes; abdomen trivittate, lateral stripes faint; eight sternite produced and narrowed posteriorly; hypopygium large, ninth tergite produced into two long, somewhat flattened triangular processes; ninth sternite with lateral appendages and posterior margin with two small median ones. Length $17 \mathrm{~mm}$. $\left(\sigma^{7}\right)$ armata *Doane

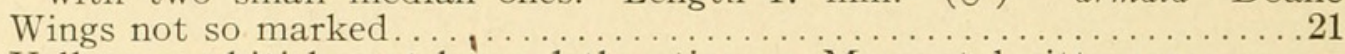

21. Yellow, a whitish spot beyond the stigma. Mesonotal vittæ more or less distinct; eight sternite semicircularly incised; ninth tergite divided by a median suture into two subrectangular processes; ninth sternite large, with downward projecting spatulate processes. Length $13 \mathrm{~mm}$. (o ). $12 \mathrm{~mm}$. (o )..............................

Brownish yellow, no white spot beyond the stigma. Thorax with three brown stripes; abdomen with three distinct brown stripes, posterior margin of segments whitish; eight sternite with rounded incision of the posterior margin, lateral angles with triangular, hooked appendages; ninth tergite with broad, deep V-shaped incision; posterior margin of ninth sternite with broad U-shaped incision, containing a pair of tumid appendages. Length $15 \mathrm{~mm} .\left(\sigma^{7}\right) \ldots \ldots \ldots$..... occidentalis Doane

22. All posterior cells more or less white. Light brown; mesonotum with four rather broad vittæ; abdomen with broad dorsal vitta; eight sternite narrowed posteriorly, emarginate at apex; ninth tergite small with deep V-shaped incision and narrow median depression; ninth sternite almost divided by a deep, U-shaped incision, containing a pair of tumid appendages. Length $11 \mathrm{~mm}$. $\left(\sigma^{7}\right)$.... acutipleura Doane

Some or all posterior cells not tinged with white ............................

23. Gray, fourth posterior cell except its apex, occupied by a fascia-like spot, $\ddagger$ first posterior cell with a spot in the middle and extreme apex white. Thorax whitish, vittæ slightly darker, not margined; abdomen trivittate. Length $14 \mathrm{~mm}$................... subfasciata Loew

Brown, posterior cells not white; the white fascia extends from before the stigma through outer parts of basal cells to the posterior margin. Mesonotum quadrivittate; anterior margin of abdominal segments darker brown; ninth tergite short, broad, with inconspicuous median ridge, posterior margin slightly emarginate, lateral angles ending in short, downward projecting processes; ninth sternite with broad, rounded incision, lateral angles with two lobed appendages. Length

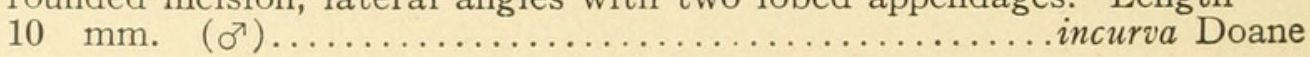

*see also 60.

†Would perhaps more properly be placed under species: "wings unicolorous, a large white spot before the stigma."

$\ddagger$ This spot can hardly be called a fascia. 
24. Wings marked with pale and fuscous spots, or the latter only $\ldots \ldots \ldots 25^{*}$

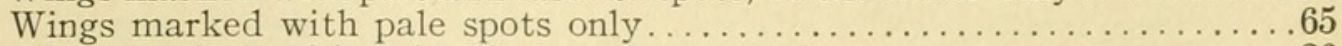

25. A spot at base of basal cells . . . . . . . . . . . . . . . . . . . . 26

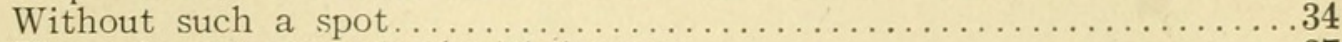

26. Thoracic vittæ margined with fuscous $\ldots \ldots \ldots \ldots \ldots \ldots \ldots \ldots \ldots \ldots \ldots 27$

Thoracic vittæ not margined . . . . . . . . . . . . . . . . . . . 33

27. Joints of flagellum bicolorous; abdomen of female very much elongated.

Abdomen with lateral stripes; hypopygium small, ninth tergite short, rather broadly emarginate, ninth sternite more narrowly emarginate. Length $15 \frac{1}{2} \mathrm{~mm}$. ( $\left.\sigma^{\top}\right) .19-20 \mathrm{~mm}$. (o )..........langiventris Loew Joints of flagellum unicolorous . . . . . . . . . . . . . . . . .

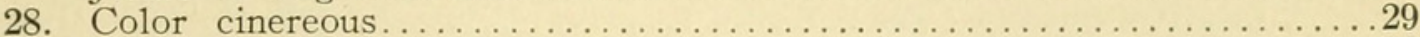

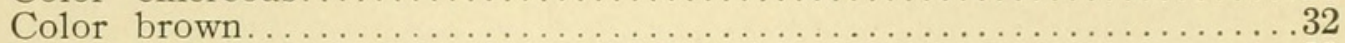

29. Entire wing with dark fuscous and white spots $\ldots \ldots \ldots \ldots \ldots \ldots \ldots \ldots \ldots$

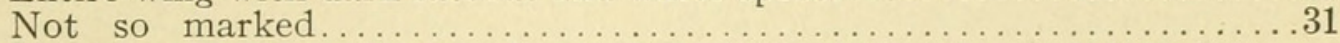

30. Fourth posterior cell almost entirely white; ovipositor serrulate benneath; abdominal stripes indistinct. Length $23-24 \mathrm{~mm}$..... tesselata Loew

First and fourth posterior cells white at base only. Abdomen with fuscous dorsal vitta and lateral lines; hypopygium small; ninth tergite small. Length $17 \mathrm{~mm}$.

septentrionalis Loew

31. Basal joints of antennæ yellowish-brown; abdomen yellowish with three brown stripes; wing veins, except in basal portion margined with fuscous. Length $30 \mathrm{~mm}$. (o . .................... leucophcea Doane

Basal joints of antennæ grayish-fuscous; abdomen yellowish fuscous, stripes indistinct; hypopygium rather large, ninth tergite rather broadly emarginate posteriorly, the emargination with a small excision in the centre; ninth sternite with large $\mathrm{V}$-shaped incision. Length

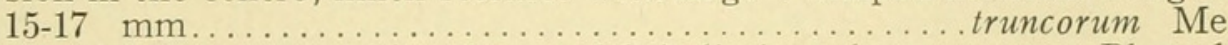

32. Thoracic vittæ very wide; pleura with indistinct, brown spots. Pleural suture of hypopygium present, though indistinct. Posterior margin of ninth tergite yellowish, with two black, triangular, downward projecting processes on its under surface; posterior margin of ninth sternite with deep, rectangular incision. Whitish spots in all the cells. Length 20-33 mm. pacifica Doane

Mesonotum with six brown stripes; pleura gray with an oblique, brown stripe. Hypopygium without pleural suture or pleural plates; ninth sternite deeply and broadly emarginate. Length $20 \mathrm{~mm}$. ( $\left.\sigma^{\top}\right) \ldots$

subcinerea Doane

33. Larger. Length over $20 \mathrm{~mm}$, testaceous.............. retorta $\mathrm{V}$. d. Wulp Smaller, not exceeding $16 \mathrm{~mm}$. Grayish black; posterior margins of abdominal segments yellowish. Hypopygium large, blackish, appendages yellowish. Wings grayish-fuscous, base of first and fourth pos-

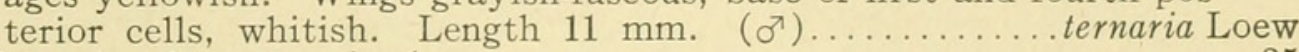

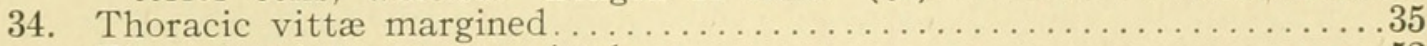

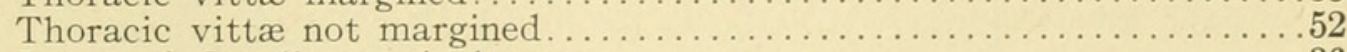

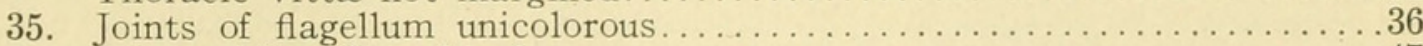

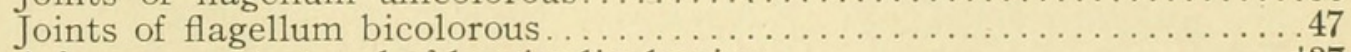

36. A fuscous spot at end of longitudinal veins . . . . . . . . . . . $\ldots \ldots \ldots$

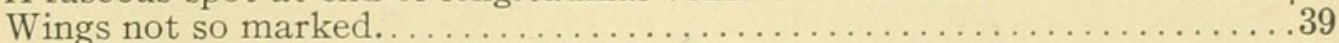

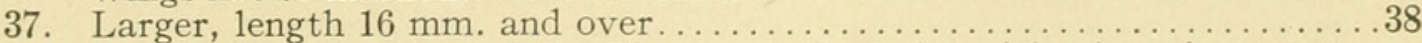

Smaller, length $10 \mathrm{~mm}$. ( $\left.\sigma^{7}\right)$. Brown; ninth tergite with a broad crescent shaped emargination. Ninth sternite with a very deep V-shaped incision. Neither pleural suture or pleural plates present. Basal half of fifth vein broadly bordered with fuscous anteriorly. Length 10

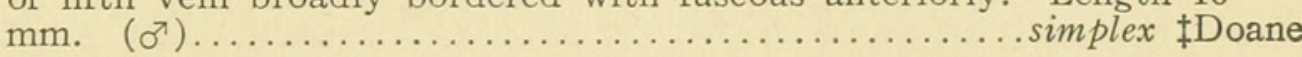

*olympia, see under 93 . unicincta, see under 138. Simulata pratorum, see Appendix.

† pubera Loew., see 57; rupicola, see 50, and abluta, see 58, belong here.

$\ddagger$ The female has rudimentary wings and should have been placed under $165-$ species with rudimentary wings in the female-. 
38. Thoracic dorsum with two velvety black spots each side behind the transverse suture. Fuscous spot at beginning of praefurca well marked. Abdomen orange-yellow above. Hypopygium small; neither pleural suture nor pleural plates; ninth tergite with a small semi-circular emargination in its posterior margin; ninth sternite with deep, oval emargination. Length $33-36 \mathrm{~mm}$...... abdominalis Say

Thoracic dorsum not as above. The fuscous spot at beginning of praefurca inconspicuous. Abdomen tawny with fuscous median stripe. Hypopygium of moderate size; ninth tergite broadly emarginate in the middle and narrowly incised laterally on its posterior margin; posterior margin of ninth sternite with a deep $\mathrm{V}$-shaped emargination. Length $20 \mathrm{~mm}$. (o $) \ldots \ldots \ldots \ldots \ldots \ldots \ldots \ldots$. cammiscibilis Doane cantaminata Daum sgn.

39. One or more posterior cells at least in part white...................40

Posterior cells not at all white. Body blackish; abdominal segment tipped with pale. Wings brownish towards the apex, a white spot at the exterior margin, surmounted by a fuscous spot. Length $11 \mathrm{~mm}$.

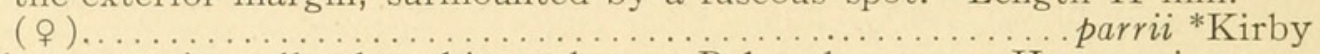

40. First posterior cell only, white at base. Pale ochraceous. Hypopygium large, ninth tergite rounded, black. Length $11 \mathrm{~mm} . \quad\left(\sigma^{\top}\right) \ldots \ldots \ldots \ldots$

More than one posterior cell white at base.....

41. Lateral appendages of the ninth sternite (below the pleural appendages) without a lower pendulous, or claw like arm. Hypopygium elongated, posterior margin of ninth tergite produced in the middle in a short, broad three pointed downward-projecting tooth; ninth sternite broadly emarginate posteriorly; from the middle of which arise two long strap-like appendages. Length $18 \mathrm{~mm}$............madera Doane

Lateral appendages with a lower pendulous, or claw-like arm.........42

42. Lateral appendages with only two arms .................... 43

Lateral appendages with three arms .......................

43. Lower arm of lateral appendage slender, membranous, nearly straight. Hypopygium large, ninth tergite with two pendulous processes at its posterior margin. Abdomen with a fuscous stripe each side. A11 posterior cells more or less white. Length $11 \frac{1}{2} \mathrm{~mm}$........ fallax Loew

Lower arm of pendulous appendage more strongly chitinized, claw-like, tip blackish.

44. Lower arm of lateral appendages short, broad, flat. Grayish brown; pleura with an interrupted brown line running from neck to base of wings; posterio-lateral margins of abdominal segments grayish. Eight sternite threelobed; posterior margin of ninth sternite with downward projecting, three toothed process; two long, slender blade like processes arise from the base of the incision of the posterior margin of the ninth sternite. Wings brownish with whitish hyaline spots in all the cells. Length $15 \mathrm{~mm}$.......................rohweri Doane

Lower arm of lateral appendages long, slender. Subtestaceous; first posterior cell almost entirely, fourth at base, white; ninth tergite without pendulous processes. Length $12-14 \mathrm{~mm} \ldots \ldots \ldots \ldots$........ grata Loew

*May not belong to the genus Tipula.

tThe differentiation of the seven species under this heading, are based on the table given in Prof. Doanes' paper, entitled "'Tipula fallax and others." Psyche Vol. XIII, pp. 160-166. In wing pattern, they, together with Tip. hebes, resemble each other very much and Tip. fallax of the West and Tip. hebes of the East may be looked upon as typical. 
45. The two upper arms of lateral appendages consist of two small, subequal, spine-like processes. Brown; pleura hoary, a brown line running from upper angle of mesopleura to neck; abdomen yellowishbrown, darker posteriorly; ninth tergite about twice as long as wide, posterior lateral angles ending in short, blunt points; posterior marposterior lateral angles enth ninth sternite with a pair of long twisted, heavily chitinized
processes. Wings brownish with a few indistinct, whitish spaces. Length $15 \mathrm{~mm}$. ( $\sigma^{7}$ and $q$ ).................. First and second arms of lateral appendages very different in size and

46. The blade-like processes arising from the posterior margin of the ninth sternite long, slender, sinuous. ish line reaching from neck to base of wing, Hypopygium much brown with three inter ninth tergite produced downward into two elongated; extreme tip of minterior margin of ninth sternite deeply short, sharp, curved claws; poster lon, slender, sinuous, blade-like notched and provided with two several whitish, hyaline spots in processes. Wings browning pattern scarcely distinguishable from nearly all the cells-wing pattern scarcely distinguishable alia Doane fallax-Length $15 \mathrm{~mm}$-...................................... Brown; abdomen with broad median and narrow lateral stripes; ninth tergite a little longer than wide, posferior margin with a pair of short, black, downward projecting processes; ninth sternite completely divided, from the incision arises a pair of rather long, thin, sharp-pointed, bladelike processes; bases of first and fourth posterior cells whitish, discal like processes, neucomeri Doane cell almost wholly white. Length $13 \mathrm{~mm} \ldots \ldots \ldots \ldots \ldots$. . . $\ldots \ldots \ldots \ldots . \ldots 48$

47. First posterior cell white at base .................... 49

First and fourth posterior cells white at base $\ldots \ldots \ldots \ldots \ldots \ldots \ldots \ldots \ldots . . .50$

First posterior cell not white at base...................... Yellowish; 48. Smaller, $13-15 \mathrm{~mm}$, ovipositor not serrulate ben large, ninth tergite large,
pleura spotted with brown. Hypopygium lath a strongly
longer than wide, narrowed posteriorly, its apex with a ninth longer than wide, nownward directed short, toothed process; ninth chitinized, black, downward directed short, sternite with deep narrow incision with pointed, sickle-shaped processes; the lateral angle of the Loew a long, pendulous process. Length $13-15 \mathrm{~mm}$.....................

Larger, $21 \mathrm{~mm}$. Testace serrulate beneath. Wings grayish-fuscous, lamellæ of ovipositor serrulate beneath. paler at their bases and fourth and fifth posterior cells some. Length $21 \mathrm{~mm}$........serrula: ${ }^{*}$ Loew along the vein separating the same. fusiform. Abdomen trivittate;

49. Color gray, median line of thorax not fusitor along posterior wing margin. wings grayish-fuscous, no white spots along posterior...discolor †Loew

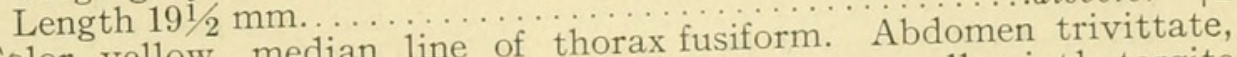

Color yellow, median line of thock. Hypopygium small, ninth tergite ultimate segments nearly black. Hypopygium sith about four whitish very small, sub-orbicular; wings pale brown with about canadensis Loew

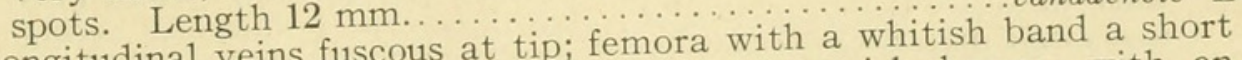

50. Longitudinal veins fuscous at tip; femora with grayish brown, with an distance before the tip. Brown, pleura Ninth tergite somewhat tumid, irregular line and spots dark fuscous. pleural suture complete, ninth sternite almoses. Length 25 mm......
posterior margin with two broad appendages. $\ddagger$ Doane

Longitudinal veins not fuscous at tip, femora without preapical white band.

*Type minus flagellum, joints of same may be unicolorous.

†Joints of flagellum toward the base pale brown, black at base, outer joints entirely dark fuscous.

† Should have been placed under 37 . 
51. Dark cinereous; abdomen sordid testaceous, indistinctly trivittate, last two segments blackish, lateral margins of segments whitish. Hypopygium small, ninth tergite reniform. Wings grayish-fuscous, a small white spot at the posterior margin of the second basal cell, discal cell and base of fourth posterior cell indistinctly whitish. Length $14 \mathrm{~mm}$.

Yellowish; thorax reddish; abdomen trivittate. Hypopygium moderately large, ninth tergite membranous posteriorly, deeply emarginate in the middle, sides deflected in the form of rounded lobes; ninth sternite entire, a somewhat ellipsoidal shaped process arises from its posterior margin. Wings strongly tinged with yellow. Length 10-24 mm.................................... flavescens Fabr

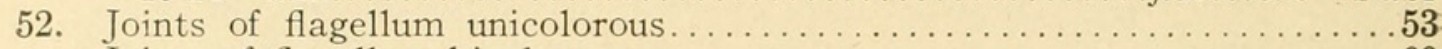

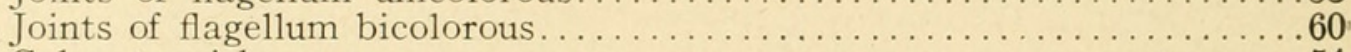

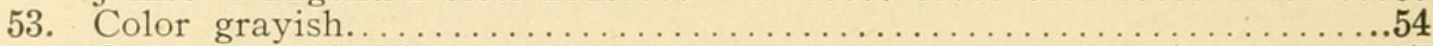

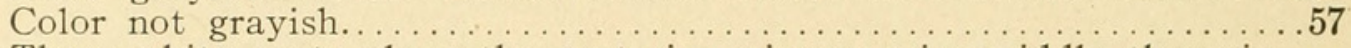

54. Three white spots along the posterior wing-margin; middle thoracic vitta obsolete anteriorly. Abdomen testaceous, lateral margins and last segments fuscous; hypopygium subcarinate below; wings grayish. Length $9-13 \mathrm{~mm} \ldots \ldots \ldots \ldots \ldots \ldots \ldots \ldots \ldots \ldots \ldots \ldots$ fragilis $\sigma^{\supset} \mathrm{Loew}$ suspecta 인ow

Posterior wing margin without three spots................... 55

55. Scutellum and metathorax shining; former yellow with a brown line in the middle. Abdomen brownish yellow, hind margin of segments and interrupted dorsal stripe brown; hypopygium rather large, ninth tergite broader than long, posterior margin with a crescent shaped emargination; ninth sternite nearly completely divided; pleural suture almost extending to the anterior margin. Wings pale gray, veins of apical portion white margined. Length $7-16 \mathrm{~mm} \ldots \ldots \ldots \ldots$ beatula $\mathrm{O}$. S.

Scutellum and metathorax not shining.

56. Abdomen shining, sutures brown, wings with three clearly defined fuscous spots along the costal margin. Length $18 \mathrm{~mm}$..... frigida Walker

Abdomen trivittate; wings with three fuscous spots along the costal margin near the apex. Length $12 \mathrm{~mm}$................. resurgens Walker

57. Pubescens of body very conspicuous. Testaceous; thoracic stripes not very distinct. Hypopygium very large; ninth sternite large, barbed at the posterior margin with golden yellow hair. Wings grayish fuscous, anterior branch of second longitudinal vein abbreviated; most of the veins margined with fuscous; all posterior cells white

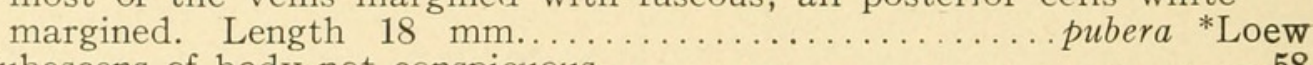

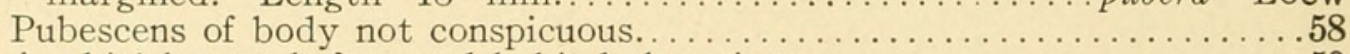

58. A whitish spot before and behind the stigma........................ 59

Wings not so marked. Brown; mesonotum with four brown stripes; abdomen with lateral stripes, latero-posterior margins of segments yellowish; eight and ninth segments separated above by a deep furrow; lateral margins of ninth tergite drawn out into a blunt point posterior$1 y$, ninth sternite divided by a deep quadrate incision. Veins in apical part of wing white margined, and tipped with fuscous; similar to commiscibilis (contaminata). Length $22 \mathrm{~mm}$. ( ( ) ..... abluta †Doane

59. The white spot before the stigma extends to base of fourth posterior cell; abdomen trivittate.

The white spot before the stigma does not extend to the posterior cells. Brownish yellow. Mesonotum with four broad, brown stripes; abdomen with broken, brown lateral stripe; ninth tergite with deep, median furrow and rather deep V-shaped incision, the apex of which bears a short triangular black tipped tooth; ninth sternite with broad, deep U-shaped incision which contains a pair of large, tumid yellow haired appendages. Veins with indistinct whitish border. Length

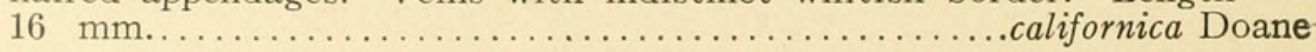

* Should have been placed under 37 .

$\dagger$ Should have been placed under 37 . 
60. Yellow; mesonotum quadro-vittate. Hypopygium large, ninth tergite produced into two long flattened sub-triangular processes; ninth sternite produced laterally into rather long very acute triangular appendages. The white spot extends through the fourth posterior cell to the posterior margin. Length $17 \mathrm{~mm} .\left(\sigma^{7}\right) \ldots \ldots \ldots$ armata $*$ Doane

Brown; mesonotum with three brown stripes; pleura slate colored. Posterior margin of abdominal segments paler; posterior margin of ninth tergite depressed shining black with median, short blunt process; ninth sternite with rounded emargination, containing a pair of rather long, tumid appendages. Wings gray with three conspicuous, white spots. Length $15-23 \mathrm{~mm}$......................lbonotata Doane

61. Abdomen pale yellowish, posterior margin of segments dark fuscous.

Abdomen not so marked. fasciata †Loew

62. Gray; ovipositor with a large, oval piceous and shining shield above, terminated by two movable, lanceolate, serrated and ferruginous lobes; penultimate joint (of abdomen) with two long, slender spines beneath; length $21-22 \mathrm{~mm} . . \ldots \ldots \ldots \ldots \ldots \ldots \ldots \ldots \ldots$ arctica $\ddagger$ Curtis

Not gray; ovipositor not so constructed. .............................. 63

63. Fuscous; abdomen ferruginous with two fuscous stripes; thorax with pale brown stripes. Wings brownish with several whitish spots and three fuscous spots near the costal margin. Length $16 \mathrm{~mm} .\left(\sigma^{7}\right) \ldots$

Yellowish species; abdomen trivittate.

platymera Walk

64. Thorax grayish, or yellowish gray; all the joints of flagellum bicolored. Hypopygium very large, pleural pieces greatly elongated, linear. Three or four fuscous spots near the anterior margin, fourth and fifth posterior cells partly white. Length $13-14 \mathrm{~mm}$......... macrolabis Loew

Mesonotum light yellow with four brown stripes. Ninth tergite ( 9 ) nearly concealed beneath the eight. Wings tinged with brown, a brown spot in the anterior margin of first basal cell, origin of praefurca and over the stigma, an incomplete whitish band before the stigma extends to base of fourth posterior cell. Length $19 \mathrm{~mm}$. (o )

65. Joints of flagellum bicolorous varia Doane

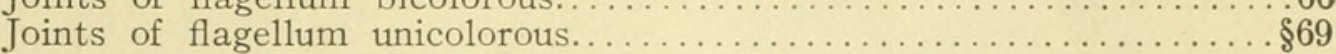

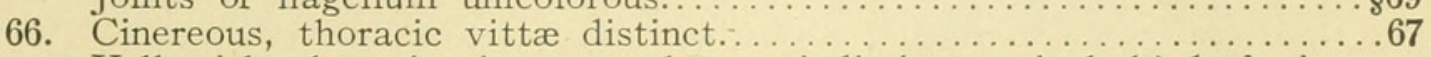

Yellowish, thoracic vittæ concolorous, indistinct; apical third of wing infuscate.

67. White spots at end of veins; mesonotum with two brown lines, confluent anteriorly; wings dusky, three or four white spots along central veins, stigma margined white; abdomen blackish; apex of femora blackish. maculalipennis Say

No white spots at end of veins; thoracic stripes margined; abdomen yellowish-gray with three dark stripes, hypopygium small, ninth tergite small, ovate; ninth sternite absent (?). Wings pale fuscous with four pale spots; base of first and fifth posterior cells white. Length

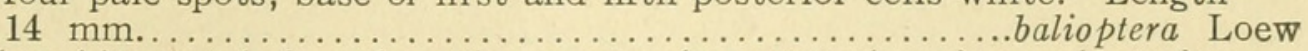

68. The white spot before the stigma extends across the wing and attains the posterior margin. Hypopygium large, ninth tergite broadly and profoundly emarginate, the lateral angles extended into sharp points; ninth sternite nearly concealed by the large, protuberant eighth sternite, pleural plates present, small, the lower angle of the right pleural plate prolonged into a two pronged process. Length $17 \mathrm{~mm}$. speciosa Loew

The white spot does not extend beyond the base of the fourth posterior cell. Smaller, and wings paler than in speciosa. Length $15-16 \mathrm{~mm}$. submaculata Loew

*See also under 20.

†See under 16.

†Tye specimens minus antennæ.

\$Indistinctly seen in T. valida, Loew; antennæ wanting in T. versi-color. 
69. Thoracic stripes not margined......................... ${ }^{*} 70$

Thoracic stripes margined............................76

70. Apical third of wing infuscate; yellowish-gray; abdomen trivittate, lateral margin and posterior margin of segments whitish; ovipositor with a semi-tubular process each side at base. The white spot in front of the stigma extends across the wing and attains the posterior margin; base of third posterior cell white. Length 19-20 mm.

Apical third of wings not infuscate. . .

................... 71

71. Abdomen black or orange colored............................. 72

Abdomen not so colored.................................... 73

72. Abdomen blackish, posterior margin of segments yellow. Black; hypopygium small, posterior margin of ninth tergite depressed with two median, longitudinal, shining black ridges; ninth sternite with a broad deep incision. Wings grayish-brown, rhomboidal, discal and fourth posterior cells almost wholly white. Length $14 \mathrm{~mm} . \quad\left(\sigma^{7}\right) \ldots \ldots \ldots$ helvocincta Doane

Abdomen orange-yellow with three black, longitudinal stripes. Wings brownish, yellowish toward the costa, with about four whitish spots, first and fourth posterior cells whitish at base. Length $15 \frac{1}{2} \mathrm{~mm}$. ( $~$ ) versicolor $\ddagger$ Loew

73. Posterior cells not at all white. Head and thorax blue-black; stripes of latter indistinct; abdomen brownish yellow, first segment black, with brown lateral stripes; ninth tergite with broad, deep, crescent shaped incision; ninth sternite with deep, V-shaped incision, almost separating the segment; pleural plates distinct. Wings with four indistinct, whitish spots. Length $16 \mathrm{~mm} . \quad\left(\sigma^{7}\right) \ldots \ldots$ nigrocorporis Doane

One or more posterior cells at least partially white....................74

74. Abdomen with median stripe. Brown; thorax with five stripes, §lateral pair confluent before and behind; a lateral black spot on each abdominal segment; whitish spots along costal border distinct, those of disc indistinct, a small brown spot near the tip. Length $20 \mathrm{~mm} . .$. .

dorsimacula Walker

Abdomen without median stripe........................... 75

75. Posterior cells one and four white at base. Pale ochreous. Hypopygium moderate, ninth tergite short with two linear processes in the middle of the posterior margin, eight sternite protuberant, emarginate at apical margin and with lateral, leaflike process each side; ninth tergite with apical V-shaped emargination, pleural suture short. Wings grayish, apex a little darker, with about four not very distinct, whit-

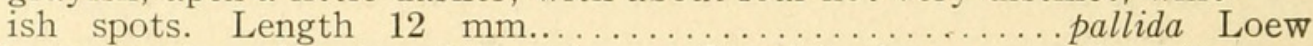

First posterior cell only, white at base. Grayish; thorax grayish white. Wings with several whitish spots. Length $12 \mathrm{~mm}$. (o ).... ignobilis Loew

*T. impudica see 121 .

$\dagger$ Mr. C. P. Alexander informs me that he has seen the type of T. valida, a female, in the Loew collection at Cambridge and that it is identical with specimens of $T$. calva, in my collection, determined as such by Prof. Doane. The type of the latter species was a male. Specimens of both species-determined as such by Prof. Doane and Mr. C. P. Alexander respectively-apparently agree in all particulars, except in coloration of the flagellar joints, which are distinctly bicolored in calva and nearly fuscous in valida. There is also a difference in the apical appendages of the two species. Loew does not mention the narrowly infuscate posterior transverse, and apical posterior of fifth veins.

$¥$ Type, a female, minus antennæ.

$\S$ In all probability it should read: thoracic stripes concolorous, margined. 
76. Posterior cells one and four white at base. Yellowish; abdomen with three fuscous stripes; hypopygium small; ninth tergite nearly divided, lobes rounded, posterior margin of each bidentate, ninth sternite with deep V-shaped emargination, containing two hairy pendulous appendages. Wings brownish with about four conspicuous, whitish spots. Length $14 \frac{1}{2}-18 \mathrm{~mm} \ldots \ldots \ldots \ldots \ldots \ldots \ldots \ldots \ldots \ldots$ serta Loew

Posterior cells one and four not white at base........................77

77. First and fifth posterior cells white at base. Brown, mesonotum with four brown stripes; abdomen with narrow lateral stripes; hypopygium small, ninth tergite terminating in a median, short and rather acute point. Wings grayish with faint, whitish spots, stigma surrounded by white, a large white spot covers tips of basal cell and base of discal and fourth and fifth posterior cells. Length $14 \mathrm{~mm}$. ( $\left.\sigma^{7}\right)$.

subtenuicornis Doane

First posterior cell only, white* at base.

78. Wing spots distinct, posterior margin of wing not white, legs rubust. Abdomen trivittate; hypopygium not large, ninth tergite short, broad, emarginate posteriorly, ninth sternite broadly and very deeply emarginate, the emargination filled by a membrane, from the posterior border of which arises a slender process which ends in two large, fleshy lobes, which are emarginate at the apex. Wings brownish, a large whitish spot, common to anal and axillary cells Length 14-221/2

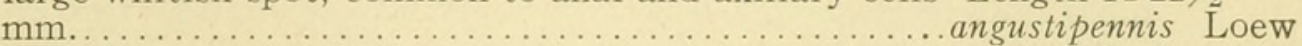

Wing spots very indistinct, posterior margin of wings whitish, legs slender; thoracic vittæ subconfluent; abdomen with black median stripe; hypopygium large with two large, pendulous appendages.

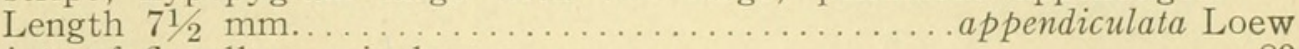

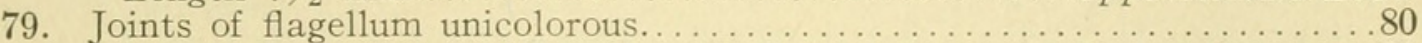

Same as all the joints of flagellum bicolorous................... 81

80. Pleura without oblique, fuscous stripe. Brown; mesonotum with three grayish-brown fuscous bordered vittæ, abdomen with broad, interrupted, brown lateral stripes, lateral margins of ninth tergite produced into short, blunt points, posteriorly; all posterior cells margined with brown. Length $16 \mathrm{~mm}$. $\left(\sigma^{7}\right) \ldots \ldots \ldots \ldots$. fuluvilineata Doane graphica Doane

Pleura with oblique fuscous stripe. Yellowish; posterior border of abdominal segments whitish; discal cell subovate, first posterior cell without subhyaline stripe. Length $13 \mathrm{~mm}$. ( $\left(\sigma^{7}\right) \ldots \ldots$.... subeluta Johnson

81. Median vitta of wing attains the apex........................... 82

Median vitta of wing does not attain the apex......................... 85

82. Costal stripe sinuous posteriorly. Thoracic stripes not sharply defined; abdomen with lateral fuscous stripes; hypopygium small, ninth tergite rounded posteriorly with a rounded, median process terminating its posterior margin, ninth sternite with a very deep $\mathrm{V}$-shaped incision; second posterior cell small, fourth and fifth white at base. Length

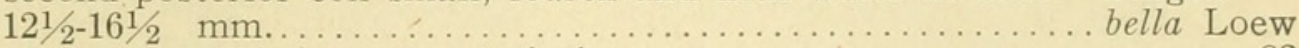

Costal stripe not sinuous posteriorly........................ 83

83. The hyaline vitta of the wing passes through the first posterior cell to the apex; abdominal segments without dark fuscous, transverse line before the posterior margin, the latter and lateral margin of segments paler. Length $14 \mathrm{~mm}$. (o )........................eluta Loew

Hyaline vitta does not pass through the first posterior cell to the apex; dark transverse line before the posterior margin of the abdominal

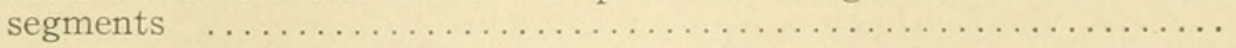

*In the male of angustipennis this cell is frequently not white. 
84. Larger, 20-28 $\mathrm{mm}$; costal border broader and more deeply fuscous; the median vitta begins about the middle of the second basal cell, basal half of anal and axillary cells whitish hyaline. Hypopygium small, exposed part of ninth tergite short, posterior margin with a median broader and two lateral, clawlike processes, ninth sternite divided to near its base by a narrow suture, posterior margin sub-triangularly emarginate, the lateral angles end in a scroll-like protuberance, pleural suture present. Length $19-25 \frac{1}{2} \mathrm{~mm}$............caloptera Loew

Smaller, 19-20 mm. Costal border less intensely fuscous, the median vitta begins near the base of the second basal cell; anal and axillary cells grayish fuscous, slightly paler at the base. Hypopygium small, ninth tergite produced posteriorly into a large, lobelike process, almost as long as the exposed part of the body of the segment, ninth sternite deeply divided to near its base; pleural suture present. Length $14-20 \mathrm{~mm} . \ldots \ldots \ldots \ldots \ldots \ldots \ldots \ldots \ldots \ldots \ldots \ldots \ldots \ldots$ strepens Loew

85. The white spot before the stigma extends across the wing in form of an irregular fascia and nearly reaches the posterior margin; part of costal border posterior to subcostal cell, paler. Length $13 \mathrm{~mm}$. (o )......

fraterna Loew

The white spot does not extend beyond the base of the fourth posterior

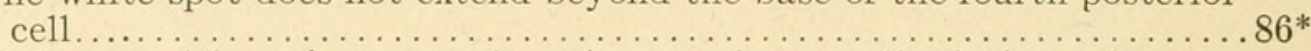

86. Abdomen without fuscous stripes; hypopygium small, ninth tergite produced posteriorly into a large, lobe-like process, at each side of the posterior margin arises a pencil of long, stiff bristles, ninth sternite deeply and rather widely divided to near its base; pleural suture present. Length 12-20 mm.......................tricolor Fahr Abdomen with fuscous, lateral stripes. Length $15 \frac{1}{4} \mathrm{~mm}$. ( $\left.\sigma^{7}\right)$.

vitrea V. d.Wuip

87. All the veins with a more or less distinct brown border. Gray, thoracic vittæ bordered with fuscous; abdomen fuscous; eight sternite distended by a tumid appendage on the ventral side of the ninth sternite, the latter with deep V-shaped incision and median suture; pleural plates present; posterior margin of ninth tergite with two close-set, black tipped projections. Wings almost hyaline with an indistinct whitish stripe in the first basal cell. Length $11 \mathrm{~mm}$...... meridiana Doane

Not all the veins bordered with fuscous............................ 88

88. Posterior cross vein and apical part of fifth longitudinal vein narrowly bordered with fuscous...................................... 89

Posterior cross vein and apical part of fifth vein not so marked.............. 94

89. Thoracic stripes margined with fuscous. Brown; joints of flagellum unicolorous, dark brown; abdomen with lateral fuscous stripes, hypopygium rather large, black, no pleural suture or pleural plates, posterior margin of ninth tergite with two slender processes. Ninth sternite with deep, broad incision and median yellow line. Wings almost hyaline, the indistinct whitish band in front of the stigma, extends to base of fourth posterior cell. Length $17 \mathrm{~mm}$. $\left(\sigma^{7}\right) \ldots \ldots$

albocaudata $\dagger$ Doane

Thoracic stripes not margined........................... 90

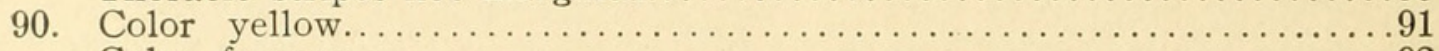

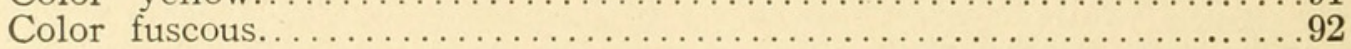

*No mention of "a white spot before the stigma" is made by the author of T. vitrea.

†Specimens in my collection determined by Prof. Doane and agreeing with his description, show a well marked, strongly curved pleural suture. 
91. Abdomen with more or less distinct fuscous stripes, lateral margins of segments broadly whitish. Joints of flagellum bicolored. Hypopygium large, eighth sternite truncate, the posterior margin with a median broad, rectangular process, lateral angles with a pair of long, rather narrow, flattened appendages; ninth tergite prolonged into two long, blunt processes; ninth sternite nearly concealed by the eight sternite; pleural plates distinct, but pleural suture nearly obliterated above. The white spot before the stigma extends to base of fourth posterior cell. Length $21 \mathrm{~mm}$. $\left(\sigma^{7}\right) \ldots \ldots \ldots \ldots \ldots \ldots$ calva *Doan

Abdomen not striped lon $\Varangle i t u d i n a l l y$, posterior margin of segments yellow. Joints of flagellum approximately unicolorous, brown; posterior border of eighth sternite emarginate with two bunches of reddish yellow hair; ninth tergite produced and narrowed posteriorly, posterior margin with crescent-shaped incision, with a median pair of short, black triangular downward projecting teeth; ninth sternite divided by a membranous area, posterior margin with two pairs of small appendages. Wings hyaline, the white antestigmatic band reaches almost to the posterior border. Length $11 \mathrm{~mm}$.. flavomarginata Doane

92. Small cross vein margined with fuscous; flagellum dark brown; abdomen with two broad dark brown stripes, lateral and posterior margins of segments grayish; the posterior lateral corners of the ninth tergite drawn out into a short blunt process (o ); Wings almost hyaline, hypopygium similar to that of albocaudata. Length 19 ( 9 ).

cognata Doane

Small cross vein not margined with fuscous

93. A spot over the base of the second submarginal and first posterior cells and a spot over the origin of the præfurca brown. Flagellum brown; mesonotum with four darker brown stripes, ninth tergite terminating into two short blunt processes. Wings with a brownish tinge. Length $15 \mathrm{~mm} .\left(\sigma^{7}\right) \ldots \ldots \ldots \ldots \ldots \ldots \ldots \ldots$ olympia Doane syn. cancinna Doane

Without spots over base of second submarginal and first posterior cells and over origin of prefurca. Joints of flagellum unicolorous; mesonotum with three brown stripes; posterior lateral angles of eight sternite with large appendages; posterior margin of ninth tergite with rounded incision, in the middle of which are two short, sharp points; ninth sternite divided by a deep, broad, U-shaped incision, containing a pair of pendulous appendages; pleural suture complete. Length

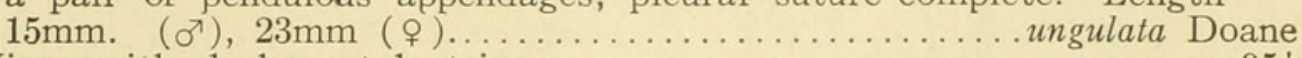

94. Wings with dark costal stripe ............................. $55 \dagger$

Wings without such a stripe, though costal margin may be a trifle darker than the rest of the wing ..........................99

95. Joints of flagellum bicolorous; costal stripe margined posteriorly by a subhyaline stripe. Abdomen dark yellowish, segments with a short, transverse fuscous line behind the anterior margin of segments 3-6 and a very small fuscous dot on the sides of all segments; hypopygium small, ninth tergite rounded posteriorly, impressed before and slightly notched in the middle of the posterior margin; ninth sternite compressed in its basal half into a carina; pleural suture distinct.

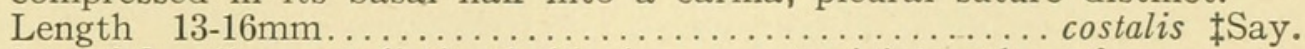

Joints of flagellum not distinctly bicolorous, outer joints at least fuscous.

Abdomen with fuscous stripe. ............................ 96

96. Costal stripe interrupted before the stigma by an indistinct hyaline

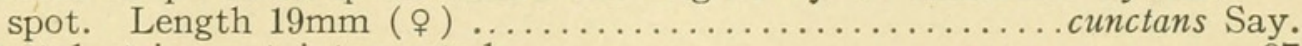

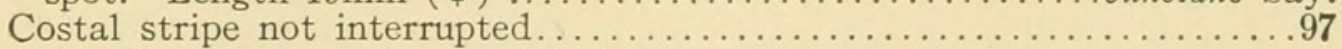

*See foot note on valida, under 70 .

$\dagger \mathrm{T}$. clara probably belongs here. See 103 .

$\ddagger$ Because costalis being preoccupied in the genus macramaxtix, Mr. C. P. Alexander has changed T. costalis to T. Sayi, a view which I cannot share, hence shall here retain Say's name. 
97. Gray, posterior margin of abdominal segments grayish-brown. Hypopygium moderately large, ninth tergite broadly and deeply emarginate, the margin notched in the middle, lateral angles produced into a process, subtruncate at the apex, ninth sternite deeply divided by a U-shaped incision, the latter containing a medium lobe-like process, lateral margins of the incision emarginate, the upper angles bearing a long pendulous process. Wings light grayish fuscous.

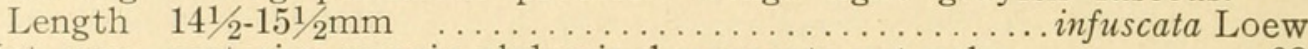

Not gray, posterior margin abdominal segments not paler............98

98. Reddish yellow, smaller. Head and thorax whitish pollinose. Hypopygium very small, compressed. Wings pale fuscous, first basal cell and margin of second a trifle paler. Length $13 \mathrm{~mm}\left(\sigma^{\top}\right)$... casta Loew*

Brown, larger. Thorax gray with four brown stripes; posterior margin of eighth sternite $\dagger$ with a median tuft of yellow hair between a pair of irregularly shaped, six-sided, box-like appendages; ninth tergite with the posterior-lateral angles produced into two broad, truncate projections; posterior margin of ninth sternite with rounded incision containing a pair of horn-like projections. Length $16-20 \mathrm{~mm} . . . .$.

99. A vitreous spot before the stigma............................ 100

Without such a spot.........................................

100. Spot lunate, extending to or beyond the discal cell ..................

Spot small, never extending beyond the second longitudinal vein ......145

101. Joints of flagellum distinctly bicolorous......................... $102 \S$

Joints of flagellum approximately unicolorous . . . . . . . . . . . . . . . . .

102. Fuscous species; abdomen with three darker stripes; eight sternite with a median process ....................................... 103 Yellowish species, costal and subcostal cells yellowish.............104

103. Costal and subcostal cells brown. Mesonotum with four darker vittæ; Posterior margin of abdominal segments paler; ninth tergite short, incised in the middle. Wings hyaline, anterior margin of anal cell fuscous, the whitish line before the stigma which extends into the base of the fourth posterior cell, very indistinct. Length

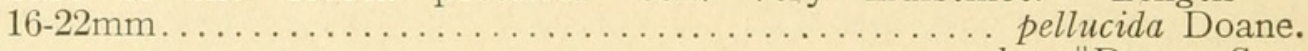
clara \|Doane, Syn.

Costal, subcostal and anterior margin of anal cells tinged with yellow. Mesonotum with three dark vittæ; lateral and posterior margins of abdominal segments paler; hypopygium small, ninth tergite with deep crescent-shaped incision, ninth sternite with deep U-shaped incision, which contains two long, tumid appendages. The white spot before the stigma reaches the extreme base of the fourth posterior

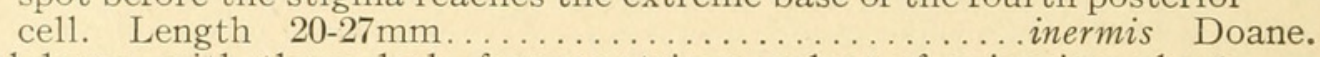

104. Abdomen with three dark, fuscous stripes, valves of ovipositor short, blade-like.

Abdominal stripes, if any, faint; if distinct, but one dorsal stripe........... 106

105. Posterior margin of ninth tergite with a short, rather broad, two pointed process, posterior margin of eight sternite with fringe of yellow hair and two strong, curved reddish bristles; ninth sternite with median depression, in which lie the tips of two short appendages; the white spot before the stigma reaches the posterior border of the discal cell. Length, $15-18 \mathrm{~mm} \ldots \ldots \ldots \ldots \ldots \ldots \ldots \ldots \ldots$ megaura Doane.

* Probably the male of cunctans Say., and according to Osten Sacken, synonymous.

†Original description says, "tergite," evidently a misprint.

$¥$ Not infrequently the space before or surrounding the stigma is paler than the general color of the wing.

$\S$ Antennæ of T. clara not described by its author.

$\|$ Prof. Doane does not mention the antennæ. 
Posterior margin of ninth tergite with a small, subquadrate median emargination, the external posterior angles extend as upturned, hornlike processes, ninth sternite nearly concealed by the eighth, bearing on each lateral posterior angle an incurved, clawlike process. The white spot scarcely reaches the extreme base of the fourth posterior

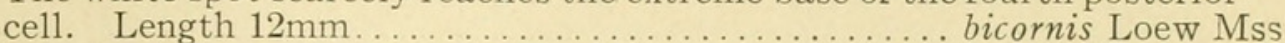

106. Thoracic vittæ and dorsal stripe of abdomen distinct; length $10 \mathrm{~mm}$.

Thoracic vittæ obsolete or indistinct.

puncticornis Macg.

107. Joints of flagellum fuscous, yellow at the base; a transverse fuscous line before the posterior margin of the abdominal segments; abdomen with lateral fuscous stripe; white ante-stigmal spot very distinct but extends as a very faint line to discal cell. Ninth tergite quadrate, posterior margin slightly emarginate in the middle with two central, digitiform processes; ninth sternite small; pleural suture present. Length $12-18 \mathrm{~mm}$.

tephrocephala Loew

Joints of flagellum yellow, fuscous at the base; abdominal segments without transverse striae before the posterior margin; lateral angle of eight sternite with a single or a pencil of two or three setæ; lateral angle of ninth tergite ending into a sharp point.

horacic vittæ obsolete; posterior margin of abdominal segments gray; the white ante-stigmal spot does not enter the fourth posterior cell. Length $15 \mathrm{~mm}$. ( $\left.\sigma^{7}\right)$. Ninth sternite emarginate, the emargination containing two pendulous processes................translucida Doane

Thoracic vittæ not obsolete, though indistinct; posterior margin of abdominal segments not paler.

109. The white ante-stigmal spot does not reach the posterior margin of the discal cell. Ninth sternite as in translucida, no white spot beyond the stigma. Length $16 \mathrm{~mm}$. ( $\left.\sigma^{7}\right) \ldots \ldots \ldots \ldots \ldots \ldots$ cincticornis Doane

The white ante-stigmal spot extends into the base of the fourth posterior cell. Ninth sternite as in translucida; a white spot beyond the

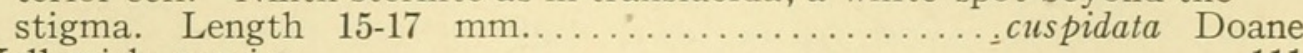

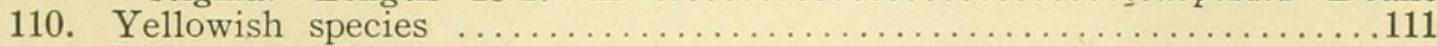

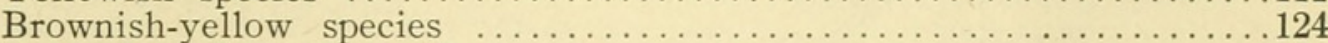

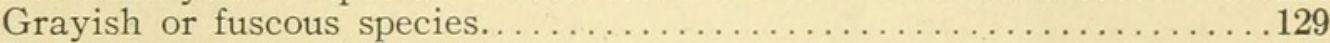

Blackish species (Northern)................................ 142

111. The ante-stigmal spot does not extend into the discal cell. Mesonotum with three broad, dark brown vittæ; abdomen trivittate; eight sternite produced and narrowed posteriorly; ninth tergite very small, produced into two blunt processes posteriorly; ninth sternite large, lateral angles produced into long, tapering, twisted, hornlike pro-

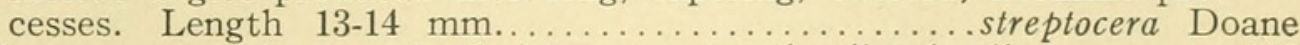

The ante-stigmal spot extends into or across the discal cell.........112

112. Posterior margin of some or all abdominal segments paler............113

Posterior margin of abdominal segments not paler................ 118

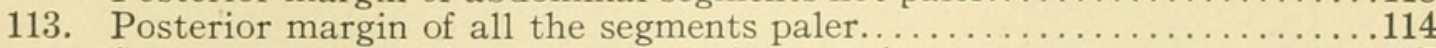

Some segments without pale posterior margin. . . . . . . . . . . . . 117

114. Abdomen with three well marked brown stripes. Mesonotum with five brown lines; joints of flagellum brown, darker at the base; lateral angles of eight sternite with two incurved reddish bristles; ninth tergite with deep broad, crescent-shaped incision; ninth sternite with deep V-shaped incision, below which is a whitish, oval process. Wings hyaline ante-stigmal spot very indistinct, but reaches the base of the fourth posterior cell. Length $18-22 \mathrm{~mm}$................. bisetosa Doane

Abdomen yellow, darker posteriorly but without longitudinal stripes; flagellum brown; ninth tergite with deep $V$-shaped incision. . . . . . . . 115 Abdomen reddish yellow, three indistinct stripes. T. lamellata, see 119. 
115. Abdominal segments 6-8 mostly black. Mesonotum trivittate; ninth sternite with deep incision, containing a pair of yellow appendages; wings hyaline, a faint brown spot over origin of praefurca, ante-stigmal spot broad, distinct, reaches base of fourth and side of fifth pos-

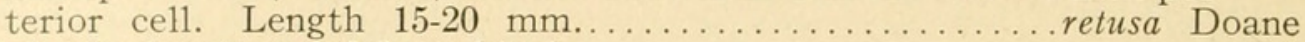

Abdominal segments $6-8$ not black. . . . . . . . . . . . . . . . . . 116

116. Mesonotal stripes and ante-stigmal spot distinct. Eighth sternite very large with median, rectangular projection of the posterior margin; ninth sternite with deep U-shaped incision, containing a long, rather broad tumid process; pleural plates distinct; fifth vein narrowly bordered with brown. Length $\left(\sigma^{7}\right) 22 \mathrm{~mm} \ldots \ldots \ldots \ldots \ldots \ldots$.............

Mesonotal stripes and ante-stigmal spot very indistinct. Eighth sternite long, narrowed posteriorly; posterior margin of ninth sternite with two processes, each bearing a tuft of hair, lateral margins with two pairs of appendages. Length $\left(\sigma^{7}\right) 12 \mathrm{~mm}$.............splendens Doane

117. Ante-stigmal spot extends to posterior margin of wing; posterior margin of abdominal segments 1-7 pale yellow. Joints of flagellum brown, yellow at the base. Mesonotum with three broad, reddish brown stripes. Abdomen trivittate, segments 8-9 wholly brown. Wings nearly hyaline. Length (o ) $20 \mathrm{~mm}$...................albofascia Doane

Ante-stigmal spot does not reach the posterior margin of wing. Abdomen with three stripes, posterior margin of segments 4-8 white; ninth tergite with deep, median impression bearing at its end a rather broad, sharp pointed process; ninth sternite with deep, white bordered incision which contains two pendulous appendages. Wings hyaline, a whitish spot beyond the stigma and two whitish, indistinct streaks just behind the sixth longitudinal vein. Length $\left(\sigma^{7}\right) 19 \mathrm{~mm}$.

albocincta Doane

118. A whitish spot beyond the stigma. Joints of flagellum darker at the base; three broad mesonotal stripes; three indistinct abdominal stripes; lateral angles of eight sternite with a pair of rather broad appendages; ninth tergite thick"swollen with median shallow furrow, posterior margin produced each side into a blunt, swollen process, deeply emarginate between the processes; ninth sternite with rounded incision which is filled by two long triangular appendages. Wings hyaline; the ante-stigmal spot extends into the base of the fourth posterior cell. Length $21 \mathrm{~mm}$. $\left(\sigma^{7}\right) \ldots \ldots \ldots \ldots \ldots$.......... hirsuta Doane

Without whitish spot beyond the stigma........................ 119

119. Mesonotal vittæ obsolete or very faint; abdominal stripes and antestigmal spots ill defined or indistinct........................... 120

Ante-stigmal spots at least distinct...............................

120. Larger, 18-20 mm., thorax yellow, shining, no stripes. Flagellum brown; posterior margin of eight sternite* with two tufts of long hair; hypopygium large; posterior margin of ninth tergite with slight median incision, lateral angles produced into short, slender acute points; ninth sternite with rather deep incision containing a pair of short appendages. Wings hyaline....................lucida Doane

Smaller, 12-13 mm. Flagellum brown; thorax not shining, stripes very faint brownish. Ninth tergite nearly completely divided, each side terminating into a point, bent at right angle to upper surface. Ninth sternite long, posterior margin with two small processes, each bearing a tuft of hair. Wings hyaline.................lamellata Doane

121. Abdomen with three black stripes; ante-stigmal spot distinct; flagellum dark fuscous.

Abdomen without such stripes; thoracic stripes very faint; ante-stigmal spot distinct extending to base of fourth basal cell.............123

*In the description it says "tergite," no doubt by misprint. 
122. Ante-stigmal spot extends into the bases of the fourth and fifth posterior cells, one or two irregular whitish hyaline spaces in anal and axillary cells. Mesonotum with four brown lines; posterior margin of abdominal segments gray; ninth tergite short, divided by deep median ncision; ninth sternite with deep, median incision. Wings with grayish tinge. Length $15-25 \mathrm{~mm}$.................... impudica Doane

Ante-stigmal spots extends into fourth posterior cell only; no hyaline spots in anal and axillary cells. Mesonotal vittæ very distinct; ninth tergite rather short, with deep broad, V-shaped emargination; ninth sternite with triangular emargination, the anterior end of which is almost circular; eight sternite with nearly semi-circular emargination; pleural plates distinct. Length 13-18 mm..praecisa Loew

123. Joints of flagellum lighth brown, darker at the base; eighth sternite not emarginate. Ninth tergite with median furrow, lateral angles slightly produced; ninth sternite divided by a rather wide membranous portion, posterior margin with a pair of two parted appendages. Wings hyaline. Length $12 \mathrm{~mm}$. rusticola Doane

Joints of flagellum fuscous; eighth sternite with shallow, broad rounded incision. Hypopygium large, ninth tergite of moderate length, narrowly emarginate in the middle, apical margin of each side very slightly emarginate; ninth sternite widely and very deeply emarginate, with a broad, subtriangular process each side. Length $18 \mathrm{~mm}$.

biarmata Doane

124. Posterior margin of abdominal segments paler..................... 125

Posterior margin of abdominal segments not paler; abdomen more or less distinctly trivittate.

125. Mesonotum yellowish with three broad brown stripes; median fuscous vitta of abdomen broad; posterior margin of eight sternite with two median short projections; median third of ninth tergite yellow, rest brown, with broad, deep incision and median depression; ninth sternite with very broad, deep U-shaped incision, lateral margin with a pair of short processes; pleural plates distinct, produced into a long, two pointed process; ante-stigmal spot indistinct and does not reach the base of the fourth posterior cell. Length 9-11 mm... atrisumma Doane streptocera Doane, see under 111.

impudica Doane, see under 122.

fulvinodus Doane, see under 140.

albicincta Doane, see under 117.

126. Mesonotum with four brown stripes; eight sternite produced, not emarginate; with a rather broad, elongated round tipped flap; ninth tergite short, divided by a deep V-shaped incision; ninth sternite elongated, deeply incised, lateral margin with long, slender pointed process. Ante-stigmal spot broken, extends into base of fourth posterior cell. Length $19 \mathrm{~mm}$. $\left(\sigma^{7}\right) \ldots \ldots \ldots \ldots \ldots \ldots \ldots \ldots \ldots$. . . . . . . . . . . .

Mesonotum with three or five brown stripes or lines; eight sternite emarginate at apex; ninth sternite deeply divided.

Ninth tergite small, bi-emarginate at the apex. Mesonotum with three brown stripes; scutellum yellow with median brown line; emargination of ninth sternite filled with two appendages, each terminating in a pair of backward projecting claws. Wings hyaline with slight brownish tint, stigma inconspicuous; ante-stigmal spot distinct, extends into the base of the fourth posterior cell. Length $18-27 \mathrm{~mm}$. planicornia Doane

Ninth tergite broadly or deeply emarginate; ante-stigmal spot reaches the base of the fourth posterior cell.......................... 128

128. Mesonotum with three broad, brown stripes; ante-stigmal spot distinct; abdominal stripes indistinct. Emargination of eighth sternite very broad, rounded; posterior margin of ninth tergite with broad and shallow emargination, the latter with yellow border and bearing in the middle a pair of blackish, triangular teeth; emargination of ninth sternite U-shaped and containing a pair of tumid appendages. Length

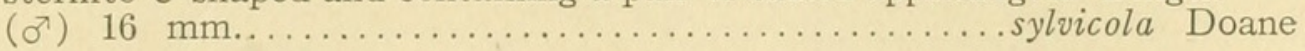


Mesonotum cinereous, with three median brown lines and two lateral, broader brown stripes; ante-stigmal spot very faint. Emargination of eight sternite very slight, rounded; emargination of ninth tergite very deep, V-shaped, latero-posterior angles sharp-pointed; lower angle of pleural plates produced into a short, blunt point. Length 12-15 mm.

biuncus Doane

129. Posterior margin of abdominal segments paler.................. 130

Posterior margin of abdominal segments not paler................ $137^{*}$

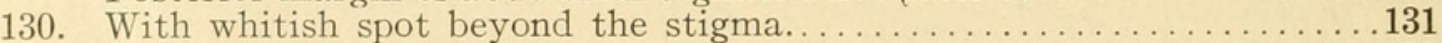

Without such a spot.................................... 133

131. Ante-stigmal spot extends through discal, fourth and fifth posterior cells to the posterior margin of the wing. Mesonotum cinereous with five brown stripes; three abdominal stripes, lateral one broader, base of first segment whitish; eight sternite produced, slightly emarginate at the apex; ninth tergite small with broad, V-shaped emargination bordered posteriorly by a yellowish, less coriaceous margin; ninth sternite deeply divided, lateral margin angulated in such a way, that the emargination is widest at the base and narrowed about the middle.

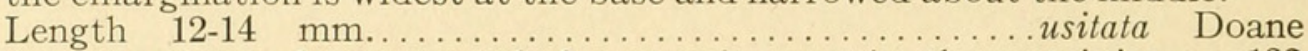

Ante-stigmal spot does not reach the posterior margin; thorax trivittate. 132

132. Mesonotum light brown; abdomen with three longitudinal, brown stripes. Posterior margin of eight sternite broadly emarginate, the * posterior margin with a fringe of thick, long, yellow hair; ninth tergite with narrow, median incision; posterior margin of ninth sternite whitish with deep median incision, on each side of which are two small appendages. Ante-stigmal spot indistinct, extends into the base of the fourth posterior cell, discal cell four times as long as wide.

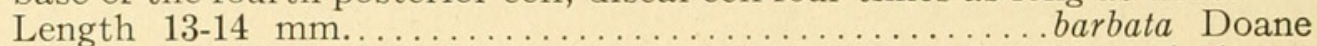

Thorax gray; abdomen without longitudinal stripes. Scutellum dark yellow; eighth sternite simple, not emarginate; hypopygium small, somewhat compressed laterally, ninth tergite small with V-shaped emargination; ninth sternite widely and very deeply divided and from the base of the emargination arises a median, digitiform, hairy process, directed horizontally backwards. Wings yellowish hyaline, veins brown, the ante-stigmal spot is inconspicuous and extends into the base of the fourth posterior cell. Length $10-14 \mathrm{~mm} \ldots \ldots \ldots \ldots . . . . .$.

aropezoides Johnson

133. Eighth sternite deeply divided; abdomen with three stripes..........133

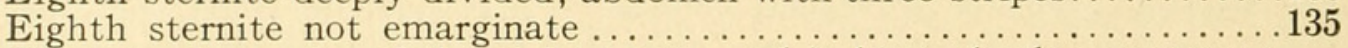

134. The lateral margins of the eight tergite end in long, slender processes; a broad blunt process arises from the base of the emargination. Mesonotum with four brown stripes; abdominal stripes indistinct; ninth tergite terminates in two short, median blunt processes; ninth sternite with deep U-shaped incision. The ante-stigmal spot distinct, interrupted at the praefurca, extends into the base of the fourth posterior

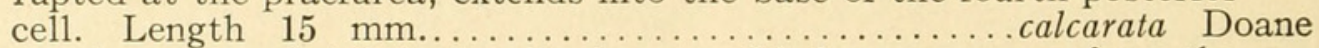

Lateral margins of eighth sternite do not end in long processes; from the emargination arise two tufts of hair; ninth sternite deeply incised.....135

135. Mesonotum with four distinct stripes; ninth tergite with broad, shallow emargination. Abdominal stripes indistinct anteriorly, lateral margins of segments gray. Ante-stigmal spot extends into the base of the fourth posterior cell. Length $15-21 \mathrm{~mm} . . . \ldots \ldots$.... aequalis Doane

Mesonotum with three brown stripes; ninth tergite with broad, deep $\mathrm{V}$-shaped incision. Abdominal stripes more distinct; ninth sternite with broad, deep depression; pleural suture very short. Ante-stigmal spot indistinct, extends into the base of the fourth posterior cell.

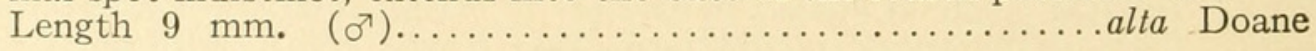

*Except fulvinodus, see under 140. 
136. Mesonotum with three broad stripes, posterior margin of eighth sternite with two short acute processes; posterior margin of ninth tergite with narrow median and two broader crescent shaped incisions; ninth sternite with deep $\mathrm{U}$-shaped incision, containing two tumid appendages. Ante-stigmal spot indistinct, not entering the fourth posterior cell.

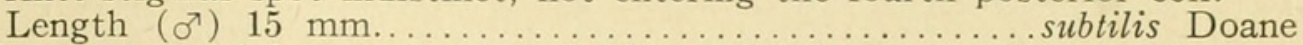

Mesonotum with four, rather broad stripes; eighth sternite with a median rather broad process. Ninth tergite short, incised in the middle; ninth sternite with deep and rather broad incision. Wings hyaline; costal, subcostal and the anterior margin of the anal cells and stigma, brown; ante-stigmal spot indistinct, extends into the base of the fourth posterior cell. Length $16-22 \mathrm{~mm}$...............clara Doane, syn.

pellucida Doane. (See also under 103.)

137. Small, $10 \mathrm{~mm}$., general reddish-brown color; thoracic stripes obsolete.* Posterior margin of segments and last three segments of abdomen dark brown. Wings light brown, veins dark brown; ante-stigmal spot reaches the posterior side of the discal cell........... jejuna Johnson

Generally larger species, color fuscous or gray.......................

138. Whitish streaks in anal, axillary and 2-5 posterior cells; a fuscous spot on basal transverse vein. Mesonotum with four stripes; abdomen with three rather indistinct lines; posterior margin of eight sternite with a small appemdage, lateral angle with a pair of larger appendages; ninth tergite ending in two rather acute points. Wings brownish tinted, ante-stigmal spot extends into base of fourth and side of fifth posterior cells. Length $19-22 \mathrm{~mm}$................... unicincta Doane

Wings without whitish streaks, no fuscous spot on basal transverse vein.

139. Eighth sternite incised.

Eighth sternite not incised; ninth tergite and ninth sternite deeply incised..141

140. No white spot beyond the stigma; ninth tergite with two small crescentshaped incisions. Brown; mesonotum with three broad brown stripes; scutellum and metanotum with narrow brown line; abdomen trivittate lateral margin of the emargination of the eighth sternite with a pair of broad, two pointed appendages; ninth sternite divided, posterior lateral angles with a pair of elongated appendages, which again are provided with a vair of slender, long, twisted and pendulous appendages. Wings with brownish tinge, ante-stigmal spot extends into the base of the fourth posterior cell. Length $19-21 \mathrm{~mm}$.......... acuta Doane

A white spot beyond the stigma, posterior margin of ninth tergite with Y-shaped incision. Mesonotum with three brown stripes each of which is divided by a gray line; abdomen trivittate, posterior margin of segments yellowish; ninth sternite with rounded incision, containing a pair of whitish appendages. Wings hyaline, ante-stigmal spot very faint, broken, extends into base of fourth posterior cell. Length

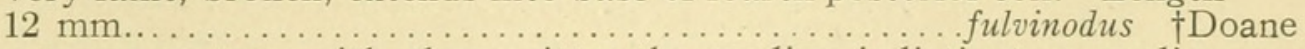

141. Gray, mesonotum with three vittæ the median indistinct, a median yellow line from transverse suture to base of abdomen, anterior margin of segments of the latter paler. Hypopygium small. Wings hyaline, with slight grayish tinge, very faint lighter streaks in nearly all the cells, stigma surrounded by an indistinct whitish cloud, which is incompletely connected with a whitish spot in the base of the discal cell. Length $10-14 \mathrm{~mm}$.

dorsolineata Doane

Fuscous; mesonotum with five, rather broad stripes, lateral ones connected anteriorly; abdomen trivittate; eight sternite large, posterior margin bearing two pairs of appendages; hypopygium large; incision of ninth sternite contains a pair of rather long, somewhat curved, tumid, pendulous appendages. Wings with light brownish tinge, ante-stigmal spot extends into base of fourth posterior cell. Length 14-17 $\mathrm{mm}$.

*No stripes mentioned in the description.

†Should have been included under 125 . 
142. Antennæ long, reach base of third abdominal segment $\left(\sigma^{\top}\right)$; front and occiput with median black line........................... 143

Antennæ of male do not reach beyond the base of the abdomen; front and occiput without median black line........................144

143. Joints of flagellum of male very slightly constricted in the middle, three mesonotal vittæ, margined with black; abdomen with black stripe each side. A yellow stripe extends from below the humerus to base of wing and scutellum; margins of median thoracic vittæ widely diverging anteriorly; margin and lower side of scutellum yellowish; hypopygium large; eighth sternite with black hair; posterior margin of ninth tergite with a pair of conical, blunt processes. Wings pale gray, the ante-stgimal spot not connected with the discal spot; a spot beyond the stigma. Length $14-18 \mathrm{~mm} \ldots \ldots \ldots \ldots \ldots \ldots \ldots$. strigata Coq

Joints 4-7 of male flagellum, strongly constricted in the middle; lateral vittæ of mesothorax obsolete, the median stripe gray, bordered with black; Abdomen sparsely clothed with short, pale yellow hair, yellow with median black vitta; hypopygium rather small, eighth sternite with sparse, short yellowish hair; ninth tergite without apical processes. White spots of wing indistinct. Length 11-13 $\left(\sigma^{7}\right)$ to

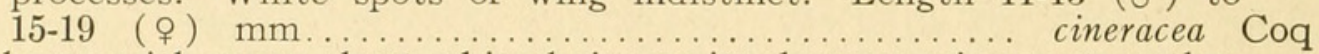

144. Thorax with many short white hairs on its dorsum; wing spots rather distinct. Abdomen black, thinly covered with short, pale yellowish hair; base of ventral surface at least, and sometimes the hind margin of some of the segments, yellow; ventral surface of eighth sternite with pale yellow hair; hypopygium and wing-spots similar to strigata.

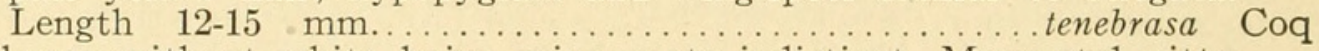

Thorax without white hairs, wing spots indistinct. Mesonotal vittæ black. Abdomen black, hind margins of segments, except the first, and lateral margins yellow, sparsely covered with very short, yellowish hair; hypopygium small; hind margin of ninth tergite destitute of processes. Length $14 \mathrm{~mm}$. $\left(\sigma^{7}\right) \ldots \ldots \ldots \ldots \ldots$..........

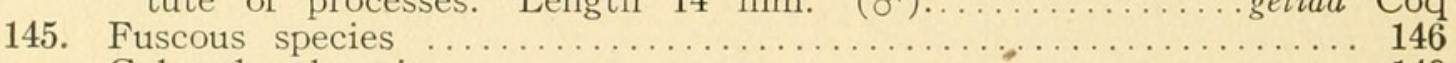

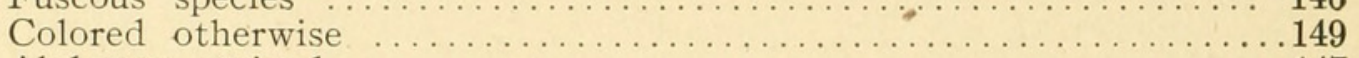

146. Abdomen striped ......................................

1 Abdomen without longitudinal stripes, posterior margin of abdominal

147. Pegments paler*
Posterior margin of abdominal segments not paler, the three longitu-
dinal stripes black. Mesonotum with six brown lines, the median stripes broad, laterals narrow. Eighth sternite with two deep folds or depressions; posterior margin of ninth tergite with two very small points; ninth sternite with median, whitish line, lateral angles with long, slender processes; wings hyaline, one or two indistinct, whitish peristigmal spots and a similar spot in the discal cell. Length

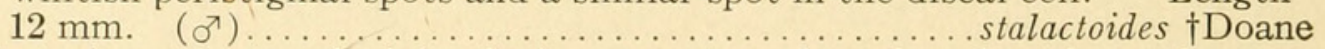

Posterior margin of abdominal segments paler, dorsal stripe paler. Antennæ wholly brown; mesonotum gray, three very broad fuscous vittæ; lateral margin of abdominal segments paler; hypopygium small, ninth tergite with median, short rectangular process, the lateral angles of which are produced into sharp, black points; ninth sternite deeply and narrowly incised; wings with brownish tinge, middle portion somewhat whitish-hyaline; ante-stigmal spot indistinct. Length $14 \mathrm{~mm} .\left(\sigma^{t}\right) \ldots \ldots \ldots \ldots \ldots \ldots \ldots . . . \ldots$ diluta Doane

\footnotetext{
Fab.

*Posterior margin of abdominal segments very indistinctly paler in dejecta
}

$\dagger$ Appears closely allied to cineracea, Coq. 
148. Antennæ wholly fuscous; mesonotal vittæ margined. Eighth tergite scarcely visible except at the sides; eight sternite entire, not emarginate; ninth tergite with two short, blunt marginal teeth; ninth sternite with deep V-shaped incision. Wings light fuscous. Length

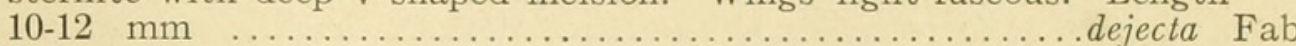

fumosa Doane syn

Antennæ brown, basal joints yellowish; mesonotum with four brown stripes, not margined. Abdomen brown, basal segments yellowish; eight sternite very large, very slightly emarginate, lateral angles with irregular shaped appendages; ninth tergite large, the lateral angles produced into long, somewhat curved, hornlike processes, which are concave within; posterior margin between these processes with two acute, triangular teeth; ninth sternite divided by a deep, broad membranous depression; pleural plates distinct. Wings hyaline. Length $17 \mathrm{~mm} .\left(\sigma^{7}\right) \ldots \ldots \ldots \ldots \ldots \ldots \ldots \ldots \ldots . . \ldots$ tergata Doane

149. Head and thorax yellow. Joints of flagellum fuscous; mesonotal vittæ very faint. Abdomen yellow at base brownish posteriorly; eighth sternite produced; narrowed posteriorly, with shallow, broad emargination, lateral angles with a pair of conical processes, bearing a pair of long, curved bristles; ninth tergite with deep median furrow, posterior margin with a pair of short, broad, blunt teeth, ninth sternite with deep, shield-shaped incision the sides of which bear a pair of rectangular plates. Wings hyaline, stigma indistinct, brown; ante-stig-

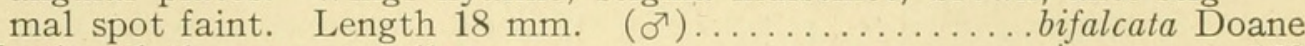
Head and thorax not yellow.

150. Head and thorax shining black. Antennæ wholly black; thorax margined with yellow; abdomen shining, sides and posterior margins of segments yellow, eighth sternite not emarginate, hypopygium small, ninth tergite small, short and almost concealed by the reflected, upper appendages; ninth sternite with suture-like incision, the posterior margin emarginate. Wings pale brown, ante-stigmal spot small but distinct. Length $9-16 \mathrm{~mm} \ldots \ldots \ldots \ldots \ldots \ldots$...........

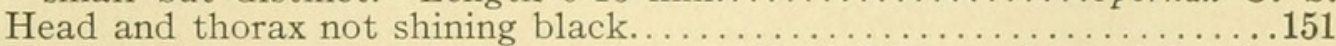

151. Head subfuscous, thorax paler; antennæ yellowish-brown, base of flagellar joints black. Lateral and posterior margin of abdominal segments paler; hypopygium small. Wings pale-brownish, stigma concolorous, ante-stigmal spot not very distinct. Length $13 \mathrm{~mm} . . . .$.

umbrosa Loew

Head and thorax ferruginous.

152. Southern species; legs very long, thorax trivittate; posterior margin of abdominal segments paler. Length $16 \mathrm{~mm}$........... perlongipes Johnson filipes Walker syn

Northern species; legs not unusually long.

153. Posterior margin of abdominal segments paler; base of abdomen not paler, the latter with broad dorsal stripe. Length $24 \mathrm{~mm}$... triplex Walker

Base of abdomen pale, posterior margin of segments not, or indistinctly

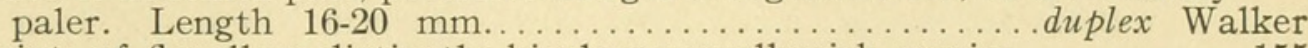

154. Joints of flagellum distinctly bicolorous; yellowish species. . . . . . . .

Joints of flagellum unicolorous................................ 156

155. Large form; outer joints of flagellum fuscous; thorax with five stripes. Posterior margin of abdominal segments paler. Wings pale tawny, irregularly colorless behind the costal border; veins dark. Length $16 \mathrm{~mm}$.

borealis Walker

Very small; all the joints of the flagellum bicolorous. Mesonotal vittæ scarcely recognizable. Posterior margins of abdominal segments slightly infuscate, hypopygium small; ninth tergite relatively large, separated from the side pieces by a distinct suture, posterior margin slightly emarginate; ninth sternite with Y-shaped incision; eighth sternite rounded posteriorly, pleural suture present, straight.

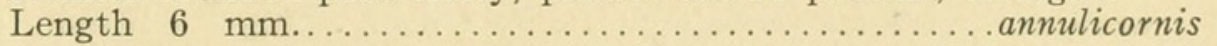




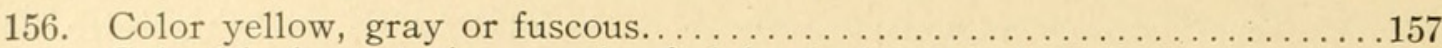

Color black; posterior margin of abdominal segments gray............164

157. Basal joints of antennæ yellow...................................

Basal joints of antennæ not yellow................................ 161

158. Yellowish species........................................ 159

Fuscous species...................................... 160

159. Antennæ long, more than half the length of the body, thorax vittate. Abdomen brownish. Wings grayish, stigma pale brown. Length

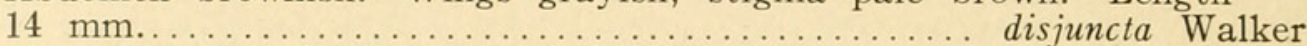

Antennæ less than half the length of the body; three vittæ of thorax as well as of the abdomen, faintly indicated; eighth sternite extending up on the sides and much produced posteriorly, posterior margin rounded, with lateral, membranous appendages; ninth tergite very large, posterior angle produced into a pair of thick, heavy, slightly curved horns, posterior margin with two broad, flattened teeth; ninth sternite almost concealed by the eighth, posterior margin biemarginate. Wings hyaline, costal and subcostal cells and stigma with yellowish brown tinge. Length $17 \mathrm{~mm} .\left(\sigma^{7}\right) \ldots \ldots \ldots \ldots \ldots$........... sternata Doane

160. Abdomen with broad dorsal stripe, basal part of ninth sternite with prominent carina. Mesonotum with faint trace of two cinereous lines; posterior margin of abdominal segments gray; hypopygium small, posterior margin of ninth tergite with crescent shaped incision; ninth sternite with crescent shaped incision. Wings with brownish tinge, subcostal cell and stigma slightly darker brown. Length $13-16 \mathrm{~mm}$.

carinata Doane

Abdomen with lateral and ventral stripes; ninth sternite not carinate. Mesonotum with three indistinct vittæ; posterior margin of abdominal segments paler; ninth sternite ending in two short, blunt points; ninth sternite with deep incision, containing a pair of long, membranous appendages. Wings with slight grayish tinge, stigma and veins brown the fifth posterior cell is not in contact with the discal cell. Length

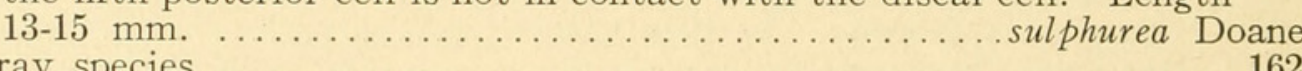

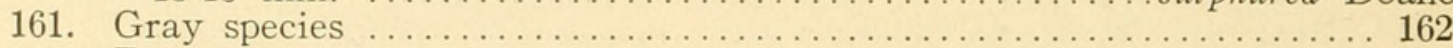

Fuscous species . . . . . . . . . . . . . . . . . . . . . . . . . . . . 163

162. Thoracic stripes margined; lateral and posterior margin of abdominal segments margined with yellowish. First antennal joint gray. Hypopygium medium sized; ninth tergite large, convex, narrowed posteriorly and terminating into a short, rounded process; ninth sternite very large, protuberant, narrowly divided, subcarinate in its basal half, about the middle of the incision is a slight protuberance, densely covered with short hair; pleural suture nearly straight, evavescent posteriorly. Wings pale brownish, somewhat infuscate at the apex, veins and stigma brown. Length $8 \mathrm{~mm}$. $\left(\sigma^{7}\right) \ldots \ldots \ldots \ldots$........... cincta Loew

Thoracic stripes not margined, lateral ones ill defined; abdomen with fuscous dorsal and ventral stripe. Head and thorax more or less clothed with pale, erect soft hairs. Hypopygium small. Wings with whitish tinge, veins and stigma brown. Length $9-13 \mathrm{~mm} \ldots$... besselsi $\mathrm{O}$. S.

163. Head with two small, tumid processes just above the base of the antennæ; abdomen with three dark fuscous stripes, posterior margin of segments paler. Mesonotum gray with five fuscous stripes. Hypopygium small, ninth tergite with U-shaped incision; ninth sternite with deep narrow incision. Wings with grayish tinge, somewhat darker along the veins and in the middle of the cells, stigma brown, praefurca short. Length $10-14 \mathrm{~mm}$....................... biturberculata Doane

Head without processes, dorsal abdominal stripe, if at all, very faint. Antennæ rather long; mesonotum with median black line and two lateral indistinct, paler lines. Eighth tergite concealed except laterally; hypopygium very small, ninth tergite with wide, crescent shaped incision; ninth sternite with lateral appendages. Wings uniformly reddish-brown, stigma concolorous, veins brown. Length 9-10 mm. $\left(\sigma^{7}\right)$. 
164. Abdomen with distinct, reddish brown dorsal stripe, lateral margins of segments not paler. Mesonotum with three gray vittæ, median indistinct. Hypopygium small, ninth tergite with a broad lobe on each side of the posterior margin; ninth sternite with deep narrow incision, with two pairs of broad appendages. Length $13-15 \mathrm{~mm}$... rostellata Doane

Abdomen not striped, lateral margin of segments gray. Head and mesonotum velvety black, latter with four rather indistinct grayish lines. Hypopygium small but rather long, ninth tergite deeply incised; ninth sternite with very deep, broad incision. Wings with grayish tinge stigma brown, veins brown, except at base of discal and second submarginal cell where they are white. Length $11-15 \mathrm{~mm}$...cervicula Doane

165. Wings of the male normally developed....................... 166

Wings of both sexes* reduced in size or rudimentary ................ 167

166. Wings of female about one half the size of those of the male. Brownishyellow; basal three joints of antennæ yellow, remainder dark brown; mesonotum vittate; abdomen with three darker stripes; eighth sternite somewhat crescent shaped, lateral margin with subtriangular appendages; posterior margin of ninth tergite somewhat crescent shaped; ninth sternite almost divided by a deep narrow, U-shaped incision; pleural plates present. Wings hyaline with smoky tinge; a whitish, ante-stigmal spot extends into the base of the fourth posterior cell; a whitish spot beyond the stigma. Length $16-20 \mathrm{~mm}$.; of wings, male $18 \mathrm{~mm}$., female $10 \mathrm{~mm}$.

Wings of female much more reduced.

Williamsi Doane simplex† Doane

167. Wings greatly reduced in size but retaining the wing-form; $4-9 \mathrm{~mm}$. long. . 168 Wings reduced to mere irregular shaped pads, less than one half the length of the halters.

168. Brownish yellow, thorax light yellow, stripes yellow (often indistinct).

Antennæ brown, basal joints yellow; abdomen with dorsal, lateral and ventral stripes; eighth sternite with broad, shallow median incision, lateral margin with broad subtriangular plates; ninth tergite with broad, circular incision with two short, median triangular processes. Wings distorted, variable in size, veins crowded. Length, male, $15 \mathrm{~mm}$.; wing 5-9 mm.; female, $22 \mathrm{~mm}$.; wing 5-6 mm....vestigipennis Doane Cinereous, thorax cinereous with four rather broad, brown stripes. Antennæ brown, basal joints yellow; abdomen with dorsal and lateral stripes. Wings much reduced in size ( $q$ ), but little longer than the halters. Length $26 \mathrm{~mm}$. (o ); wings $4 \mathrm{~mm} \ldots \ldots \ldots \ldots \ldots$......... sylvestra Doane

169. Brown; antennæ wholly brown; thorax with median darker stripe; halters rather long and slender; abdomen with broad dorsal stripe; hypopygium rather small, ninth tergite with median groove and with deep, broad U-shaped incision containing two short sharp processes; ninth sternite almost completely divided by a narrow deep, V-shaped incision. Length $4-6 \mathrm{~mm} \ldots \ldots \ldots \ldots \ldots \ldots \ldots \ldots \ldots \ldots$...................... Doane

\section{APPENDIX.}

The following two species were not included in the synopsis:

T. pratorum Kirby.

Head and thorax slate colored, the latter with four brown stripes; antennæ fuscous, scape yellow. Abdomen yellow, with a fuscous dorsal stripe; hypopygium black. Wings subfuscous, clouded with white in the male, one or two fuscous spots near the anterior margin, stigma black, $24 \mathrm{~mm}$.

Wings of female not clouded with white.

T. simulata Walk . .

Fuscous, palpi and antennæ black, the latter about one-half the length of the thorax, fuscous, scape tawny, stripes indistinct. Abdomen dull testaceous with fuscous stripe. Wings hyaline with several brown spots, which are darkest along the costa. $20 \mathrm{~mm}$.

* Male of sylvestra not known.

†See under 37 . 
List and Bibliography of the North American species of the genus Tipula L. described since the publication of the Catalogue of the North American Diptera, by Prof. J. M. Aldrich.

acutipleura Doane. Annals Ent. Soc. of Amer., Vol V, p. 42. San Diego, Cal. albimacula Doane. Annals Ent. Soc. of Amer., Vol V, p. 51. Arizona.

alia Doane. Psyche, Vol. XVIII, p. 161. Keyport and Olympia, Wash.

alta Doane. Annals Ent. Soc. of Amer., Vol V, p. 44. Landes, Wyoming. aspersa Doane. Annals Ent. Soc. of Amer., Vol. V, p. 51. Pacific Grove, Cal. atrisumma Doane. Annals Ent. Soc. of America, Vol. V, p. $42 . \quad$ San Diego, Cal. biarmata Doane. Annals Ent. Soc. of Am., Vol. V, p. 55. Keyport, Wash. bifalcata Doane. Annals Ent. Soc. of Am., Vol. V, p. 55. San Diego, Cal. biuncus Doane. Annals Ent. Soc. of Am., Vol. V, p. 58. Southern California. californica Doane. Annals Ent. Soc. of Amer., Vol. V, p. 49. Palo Alta, Cal. coloradensis Doane. Psyche, Vol. XVIII, p. 164. Tabernash, Col. commiscibilis Doane. Annals Ent. Soc. of Am., Vol. V, p. 61.

Doane. Jour. N. Y. Ent. Soc. IX, 121 (contaminata).

cylindrata Doane. Annals Ent. Soc. of Am., Vol. V, p. 46. San Diego, Cal.

derbyi Doane. Annals Ent. Soc. of Am., Vol. V, P. 47. Stanford University, Cal. flavicoma Doane. Annals Ent. Soc. of Am., Vol. V, p. 57. Montana.

flavocauda Doane. Annals Ent. Soc. of Am., Vol. V, p. 60. San Diego, Cal. flavomarginata Doane. Annals Ent. Soc. of Am., Vol. V, p. $46 . \quad$ San Diego, Cal. fulvinodus Doane. Annals Ent. Soc. of Am., Vol. V, p. 45. Grand Coulee, Wash. fulvilineata Doane. Annals Ent. Soc. of Am., Vol. V, p. 61.

Doane. Jour. N. Y. Ent. Soc., IX, 124 (graphica).

incurva Doane. Annals Ent. Soc. of Am., Vol. V, p. 43. Nebraska.

jejuna Johnson. Prof. Boston Soc. Nat. History, Vol. XXXIV, p. 132. Wellesley, Mass.; Riverton, N. J.

madera Doane. Psyche. Vol. XVIII, p. 162. Carte Madera Creek, near Stanford University; Stanford University.

marina Doane. Annals Ent. Soc. of Am., Vol. V, p. 44. Palo Alta, Cal. neucomeri Doane. Psyche, Vol. XVIII, p. 163. Deer Park, Cal. nigrocorporis Doane. Annals Ent. Soc. of Am., Vol. V, p. 45. San Diego, Cal. occidentalis Doane. Annals Ent. Soc. of Am., Vol V, p. 59. San Diego, Cal. olympia Doane. Annals Ent. Soc. of Am., Vol. V, p. 61.

Doane. Jour. N. Y. Ent. Soc., IX, 115 (concinna).

oropezoides Johnson. Psyche, Vol. XVIII, p. 131. North Adams, Mass.; Framingham, Mass.; Hazelton, Pa. Dietz.

pacifica Doane. Annals Ent. Soc. of Am., Vol. V, p. 48. Deer Park, Placer Co., Cal.

pellucida Doane. Annals Ent. Soc. of Am., Vol. V, p. 61.

Doane. Jour. N. Y. Ent. Soc., IX, 104 (clara).

planicornia Doane. Annals Ent. Soc. of Am., Vol. V, p. 52. San Diego, Cal.

pyramis Doane. Annals Ent. Soc. of Am., Vol. V, p. 53. Pyramid Lake, Nevada. quaylii Doane. Psyche. Vol. XVI, p. 18. Yuba City, Cal.

rohweri Doane. Psyche. Vol. XVIII, p. 165. Big Horn Co., Wyoming; East

Bolter, Can. Dietz.

rupicola Doane. Annals Ent. Soc. of Am., Vol. V, p. 50. Oak Creek Canon, Arizona.

rusticola Doane. Annals Ent. Soc. of Am., Vol. V, p. 47. San Diego, Cal. spatha Doane. Annals Ent. Soc. of Am., Vol. V, p. 59. Arizona.

sternata Doane. Annals Ent. Soc. of Am., Vol. V, p. 56. Stanford University, California.

subeluta Johnson. Bull. Amer. Museum Nat. History, Vol. XXXII, p. 42. Everglade, Florida.

sylvestra Doane. Psyche, Vol. XVI, p. 18. Pacific Grove, California.

sylvicola Doane. Annals Ent. Soc. of Am., Vol. V, p. 53. Keyport, Wash.

tergata Doane. Annals Ent. Soc. of Am., Vol. V, p. 56. Pyramid Lake, Nevada. ungulata Doane. Annals Ent. Soc. of Am., Vol. V, p. 54. San Diego, Cal.

vestigipennis Doane. Psyche, Vol. XV, p. 47. San Francisco, Stanford University, California.

vittatapennis Doane. Annals Ent. Soc. of Am., Vol. V, p. 61.

Doane, Jour. N. Y. Ent. Soc. IX, 119 (albovittata).

Williamsii Doane. Psyche, Vol. XVI, p. 14. San Francisco, Cal. 


\section{$2 \mathrm{BHL}$ Biodiversity Heritage Library}

Dietz, W G. 1913. "A synopsis of the described North American species of the Dipterous genus Tipula L." Annals of the Entomological Society of America 6, 461-484. https://doi.org/10.1093/aesa/6.4.461.

View This Item Online: https://www.biodiversitylibrary.org/item/42403

DOI: https://doi.org/10.1093/aesa/6.4.461

Permalink: https://www.biodiversitylibrary.org/partpdf/15344

\section{Holding Institution}

Smithsonian Libraries

\section{Sponsored by}

Smithsonian

\section{Copyright \& Reuse}

Copyright Status: NOT_IN_COPYRIGHT

This document was created from content at the Biodiversity Heritage Library, the world's largest open access digital library for biodiversity literature and archives. Visit BHL at https://www.biodiversitylibrary.org. 